\title{
A Private Ordering Solution to Blockholder Disclosure
}

\author{
Joshua Mitts*
}

\begin{abstract}
The recent debate over reforming the Securities Exchange Act section 13(d) ten-day filing window demonstrates the importance of balancing the costs and benefits of delayed blockholder disclosure in both consequentialist and deontological terms. While hedge fund activism may create shareholder value, short-termism is a very real problem for firms today. Rather than a rigid mandatory rule, the duration of the blockholder disclosure window should be set through a shareholder amendment to the corporate bylaws that empowers shareholders to set an optimal maximum length for each firm. To internalize the economic and moral costs to society of permitting trading on asymmetric information, the SEC should impose a filing fee on blockholders utilizing the delayed disclosure window and use the proceeds to compensate investors who sold shares while a blockholder engaged in a stealth accumulation.
\end{abstract}

* J.D. Candidate, 2013, Yale Law School. joshua.mitts@yale.edu. The author would like to thank Ian Ayres, Alidad Damooi, and Eric Robinson for providing valuable comments. 


\section{TABLE OF CONTENTS}

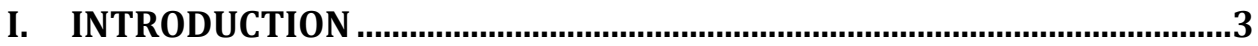

II. DELAYED BLOCKHOLDER DISCLOSURE UNDER SECTION 13(D) OF

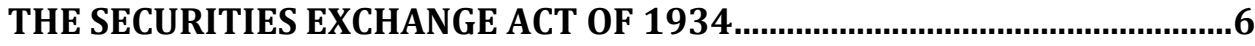

A. SECTION 13(D) OF THE SECURITIES ExCHANGE ACt OF 1934 AND STEALTH ACQUISITIONS DURING THE TEN-DAY WINDOW ……..................................................

B. LEGISLATIVE History: THE WILLIAMS ACT OF 1968 AND SECTION 929R OF

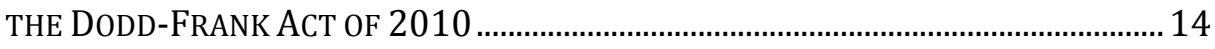

C. The ACAdemic and Policy Debate Over Shortening the TEn-Day

WINDOW. 18

III. THE COSTS AND BENEFITS OF DELAYED BLOCKHOLDER

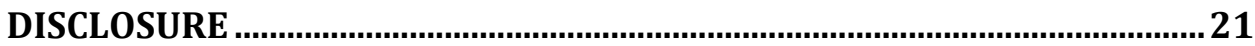

A. CReating VAlue BY Monitoring ANd Disciplining ManagemenT.............. 21

1. Agency Costs, Hedge Fund Activism and Shareholder Value ...............21

2. Inefficient Markets and Long-Term Value Creation ................................24

B. Destroying VAlue Through SHORT-Termism: A Summary OF THE

MANAGEMENT AND ACCOUNTING RESEARCH................................................................ 27

C. THE SOCIAL EXTERNALITIES OF DELAYED BLOCKHOLDER DiSClOSURE............ 31

1. Impairing Liquidity, Higher Transaction Costs and Chilling Effects. 31

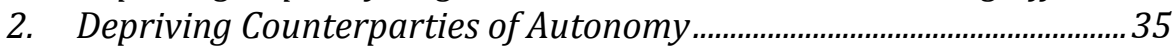

IV. PRIVATE ORDERING, FEES AND COMPENSATION .............................38

A. Why a Single MANDATORY DisCloSURE DURATION IS SUBOPTIMAL.............. 39

B. PRIVATE ORDERING FOR FIRM-SPECIFIC DELAYED DISCLOSURE ....................... 43

1. Private Ordering: Background and Proxy Access....................................43

2. Implementing Private Ordering for Blockholder Disclosure.................. 47

C. INTERNALIZING THE SOCIAL COST OF DELAYED BLOCKHOLDER DISCLOSURE: A

FILING FEE AND COMPENSATION PROPOSAL …….................................................... 53

1. A Sliding-Scale Filing Fee for Delayed Disclosure ...................................53

2. Compensating Victims of Delayed Disclosure.......................................... 61

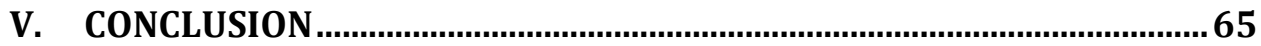

VI. APPENDIX: A SIMPLE MODEL AND CHALLENGES OF STATISTICAL

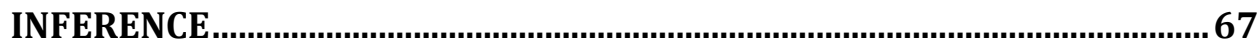


A PRIVATE ORDERING SOLUTION TO BLOCKHOLDER DISCLOSURE

$1 / 10 / 13$

\section{INTRODUCTION}

The latest round in the corporate governance tug-of-war between management and activist shareholders is the controversy over reforming the Securities Exchange Act of 1934 section 13(d) filing window. In fall 2010, activist hedge funds exploited the ten-day window to acquire $26.7 \%$ of J.C. Penney and $10.9 \%$ of Fortune Brands. By engaging in massive purchases between crossing the $5 \%$ threshold and the required disclosure ten days later, these hedge funds stealthily accumulated shares at a discount of nearly \$230 million from the post-disclosure market price. ${ }^{1}$ More recently, in October 2012, Carl Ichan exploited the ten-day window to stealthily acquire $9.98 \%$ of Netflix, yielding $\$ 52$ million in potential profit on the stake acquired during the filing window alone. ${ }^{2}$

In a recent petition submitted to the Securities and Exchange Commission ("SEC"), the law firm Wachtell, Lipton, Rosen \& Katz ("Wachtell Lipton") requested that the SEC exercise its rulemaking powers under the Dodd-Frank Act and shorten the window for filing a notice of beneficial ownership to one day. ${ }^{3}$ Wachtell Lipton argued that examples such as J.C. Penney and Fortune Brands demonstrate the potential for hedge funds to exploit the ten-day window and stealthily accumulate massive blocks of ownership. Such stealth accumulations deprive those who sold shares during the filing window of the premium they could have received upon disclosure of the hedge fund's stake.

In response to Wachtell Lipton's proposal, law professors Lucian A. Bebchuk and Robert J. Jackson articulated economic justifications for the ten-day window. ${ }^{4}$ Bebchuk and Jackson argued that announcements of hedge fund activism correlates with higher share prices, suggesting that it

\footnotetext{
${ }^{1}$ See discussion infra Section II.A.

${ }^{2}$ See id.

${ }^{3}$ Letter from Wachtell, Lipton, Rosen \& Katz to Elizabeth M. Murphy, Secretary, U.S. Sec. \& Exch. Comm'n 6 (Mar. 7, 2011), available at http://www.sec.gov/rules/petitions/2011/petn4-624.pdf.

${ }^{4}$ E.g., Lucian A. Bebchuk \& Robert J. Jackson Jr., The Law and Economics of Blockholder Disclosure, 2 HARV. BUS. L. REV. (forthcoming, 2012), available at http://papers.ssrn.com/sol3/papers.cfm?abstract_id=1884226.
} 
is beneficial for target firms. ${ }^{5}$ However, because hedge funds do not acquire a controlling stake, they cannot capture the entire benefits of intervention. ${ }^{6}$ Bebchuk and Jackson claimed that enabling activist shareholders to buy shares at a discount during the ten-day window is essential compensation for the beneficial intervention they bring to target firms. ${ }^{7}$ In response, Wachtell Lipton asserted that economic analysis does not justify undermining the purpose of the Williams Act. ${ }^{8}$

This Article advocates a balanced approach to this debate and a novel proposal for regulatory reform. Securities regulation should neither solely promote the historical goals of the 1960s nor consider only the benefits of hedge fund activism. If delayed blockholder disclosure functions as compensation for hedge fund activism, determining the optimal length of the disclosure window necessitates considering the costs and benefits of hedge fund activism — not solely one or the other.

The benefits are well-known. As Bebchuk, Jackson, and a growing number of empirical finance studies demonstrate, hedge funds are particularly effective at mitigating agency costs and increasing shareholder value. They are free from the regulatory restraints and structural limitations of traditional institutional investors like mutual funds and have strong incentives to obtain outstanding objective returns.

On the other hand, hedge funds are preoccupied with short-term results. Two scholars put it nicely: "Hedge funds come close to being the archetypal short-term investor. For some funds, holding shares for a full day represents a 'long-term' investment.", It is hard to believe that managers ignore the pressure from short-term investors simply because the efficient markets hypothesis says they should. But there's no need to resort to intuition: numerous empirical studies in the management and

${ }^{5} I d$. at $* 13$.

${ }^{6} I d$. at $* 16$.

${ }^{7} I d$. at $* 17$.

${ }^{8}$ Adam O. Emmerich, Theodore N. Mirvis, Eric S. Robinson \& William Savitt, Fair Markets and Fair Disclosure: Some Thoughts on the Law and Economics of Blockholder Disclosure, and the Use and Abuse of Shareholder Power at *2 (Columb. L. \& Econ. Working Paper No. 428, Aug. 27, 2012), available at http://papers.ssrn.com/sol3/papers.cfm?abstract id=2138945.

${ }^{9}$ Marcel Kahan \& Edward B. Rock, Hedge Funds in Corporate Governance and Corporate Control, 155 U. PA. L. REV. 1021, 1085 (2006) 
accounting disciplines have shown that short-termism is a problem in corporate America. Even if finance theory says they shouldn't, managers do feel the pressure of short-term earnings. It is hard to believe that hedge funds' demands for immediate results will have no effect on the long-term profitability of target firms.

Delayed blockholder disclosure also imposes a cost on society. Hedge funds stealthily buying shares during the ten-day window are trading on asymmetric information, and information asymmetries harm everyone in the market by reducing liquidity and raising bid/ask spreads. These stealth accumulations are not doctrinally insider trading, but their effects are quite similar. In addition to the chilling effect caused by playing a losing game with the deck stacked against unknowing retail investors, trading on asymmetric information is fundamentally unfair. It deprives market participants of autonomy by exploiting the non-disclosure of material facts regarding the share accumulation by an activist investor. Mere participation in a market that legally permits trading on asymmetric information does not imply a subjective waiver of the moral entitlement to a fully informed decision. In short, hedge funds profit from inducing others to trade on a deceptive premise regarding the status quo when they actually intend to upend it — and that imposes a moral cost on society.

To balance the costs and benefits of delayed blockholder disclosure, this Article proposes a private ordering solution akin to the approach taken for proxy access under Rule 14a-8. It may be economically efficient for certain firms to permit some delay. Rather than imposing a rigid mandatory rule, the SEC should let shareholders make this decision through a shareholders amendment to the corporate bylaws. Allowing each firm to decide how long after acquiring a 5\% stake blockholders can trade before mandating disclosure would empower shareholders to incentivize the level of hedge fund activism that would maximize the value of their shares.

Regulators, on the other hand, should focus on the price society pays when blockholders engage in stealth accumulations and profit by trading on asymmetric information. This Article proposes imposing a filing fee to induce the socially optimal disclosure duration for each firm. Under this proposal, hedge funds filing schedule 13D disclosures after passing the $5 \%$ threshold would pay a fee based on an approximation of 
A PRIVATE ORDERING SOLUTION TO BLOCKHOLDER DisClOSURE

the cost this delay imposes on society. Like a carbon tax on pollutionemitting factories, a delayed disclosure fee forces hedge funds to internalize the social cost of stealth accumulations and tacit deception of trading counterparties.

The proceeds of this delayed disclosure fee should be used to establish a compensation fund to ameliorate the injury to shareholders who sold during the delayed disclosure window. While this fund would not make injured investors perfectly whole, it would go a long way towards offsetting the exploitation of information asymmetries permitted by the private ordering system. The combination of empowering shareholders to determine the length of the disclosure window, imposing a filing fee on stealth accumulations and compensating victims would bring society the benefits of hedge fund activism while minimizing collateral consequences to the extent possible.

Part II of this Article presents an overview of delayed blockholder disclosure under section 13(d) of the Securities Exchange Act of 1934. Part III discusses the costs and benefits of hedge fund activism, the primary justification for permitting delayed blockholder disclosure. Part IV presents this Article's private ordering solution and the filing fee and compensation proposals. Part V concludes this Article.

\section{DELAYED BLOCKHOLDER DisClOSURE UNDER SECTION 13(D) OF THE SECURITIES EXCHANGE ACT OF 1934}

This Part presents an overview of section 13(d) of the Securities Exchange Act of 1934, which requires disclosing the acquisition of beneficial ownership of more than $5 \%$ of a class of reporting company's stock. It discusses the recent exploitation of this window by two hedge funds and the immense profit they obtained. In addition, this Part summarizes the legislative history of the ten-day disclosure window and the Dodd-Frank provision that grants the SEC the authority to shorten the disclosure window. It concludes by describing the academic and policy debate over this issue. 
A PRIVATE ORDERING SOLUTION TO BLOCKHOLDER DISCLOSURE

$1 / 10 / 13$

\section{A. Section 13(d) of the Securities Exchange Act of 1934 and Stealth Acquisitions During the Ten-Day Window}

Section 13(d) of the Securities Exchange Act of 1934, as amended, provides:

Any person who, after acquiring directly or indirectly the beneficial ownership of any equity security of a class which is registered pursuant to section 78l. . . or otherwise becomes or is deemed to become a beneficial owner of any of the foregoing upon the purchase or sale of a securitybased swap that the Commission may define by rule, and is directly or indirectly the beneficial owner of more than 5 per centum of such class shall, within ten days after such acquisition or within such shorter time as the Commission may establish by rule, file with the Commission, a statement containing . . . the following information ... ${ }^{10}$

The statute defines a series of required disclosure items, including identifying information regarding the beneficial owner; ${ }^{11}$ the source and amount of the funds for the purchase; ${ }^{12}$ whether the purpose of the acquisition is to acquire control, liquidate, or perform other "major changes" to the "business or corporate structure" of the issuer; ${ }^{13}$ and the number of shares beneficially owned. ${ }^{14}$ The Securities and Exchange Commission has implemented this statute in Regulation 13D of the Securities Exchange Act of 1934, which provides for filing the beneficial ownership disclosure in Schedules 13D and 13G and sets forth the technical requirements for filing. ${ }^{15}$

Crucially, section 13(d) does not require filing the disclosure statement until ten days after the acquisition of beneficial ownership of

${ }^{10} 15$ U.S.C.A. § $78 \mathrm{~m}(\mathrm{~d})(1)$ (West 2012).

${ }^{11} I d$. at $\S 78 \mathrm{~m}(\mathrm{~d})(1)(\mathrm{A})$.

${ }^{12} I d$. at $\S 78 \mathrm{~m}(\mathrm{~d})(1)(\mathrm{B})$.

${ }^{13} I d$. at $\S 78 \mathrm{~m}(\mathrm{~d})(1)(\mathrm{C})$.

${ }^{14} \mathrm{Id}$. at $\S 78 \mathrm{~m}(\mathrm{~d})(1)(\mathrm{D})$.

${ }^{15}$ See 17 C.F.R. § 240.13D-1 to 240.13D-102 (2012). 
more than $5 \%$ of the shares of any class. This permits investors to acquire a block of shares substantially greater than $5 \%$ prior to the expiration of the ten-day window. As noted in a recent petition to the SEC by the law firm Wachtell, Lipton, Rosen \& Katz ("Wachtell Lipton”), the recent examples of hedge fund acquisitions of J.C. Penney and Fortune Brands stock dramatically illustrate this phenomenon. ${ }^{16}$ Two activist hedge funds-Pershing Square Capital Management and Vornado Realty Trust $^{17}$-acquired $26.7 \%$ ownership of J.C. Penney by exploiting the tenday window. Prior to crossing the 5\% threshold, Pershing Square held $4.9 \%$ of J.C. Penney. During the window, Pershing and Vornado made a series of rapid purchases to reach the $26.7 \%$ level. ${ }^{18}$ Similarly, Pershing Square went from under 5\% to over 10\% ownership in Fortune Brands during the delayed disclosure window. ${ }^{19}$

The following graphs of the share prices of J.C. Penney and Fortune Brands during this time period vividly illustrate these stealth acquisitions and profit potential:

${ }^{16}$ See Letter from Wachtell, Lipton, Rosen \& Katz to Elizabeth M. Murphy, Secretary, U.S. Sec. \& Exch. Comm'n (Mar. 7, 2011), available at http://www.sec.gov/rules/petitions/2011/petn4-624.pdf.

${ }^{17}$ While Vornado Realty Trust is technically a real estate investment trust, it functions as an activist hedge fund. See Brad Thomas, Vornado Realty Trust: Simply A Hedge Fund In A REIT Wrapper, SEEKING AlPHA (Oct. 15, 2012), http://seekingalpha.com/article/923481-vornado-realty-trust-simply-a-hedge-fund-in-areit-wrapper.

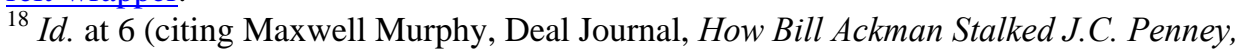
WaLl ST. J., October 8, 2010; Joann S. Lublin \& Karen Talley, Big Shoppers Bag 26\% of J.C. Penney, Wall St. J., October 9, 2010).

${ }^{19}$ Id. (citing Matt Phillips, MarketBeat, Ackman in Action, WALl ST. J. (Oct. 8, 2010); David Kesmodel, Fortune Brands Plans to Split Up, WALL ST. J. (Dec. 8, 2010)). 
Figure 1: J.C. Penney Company Inc. (JCP)

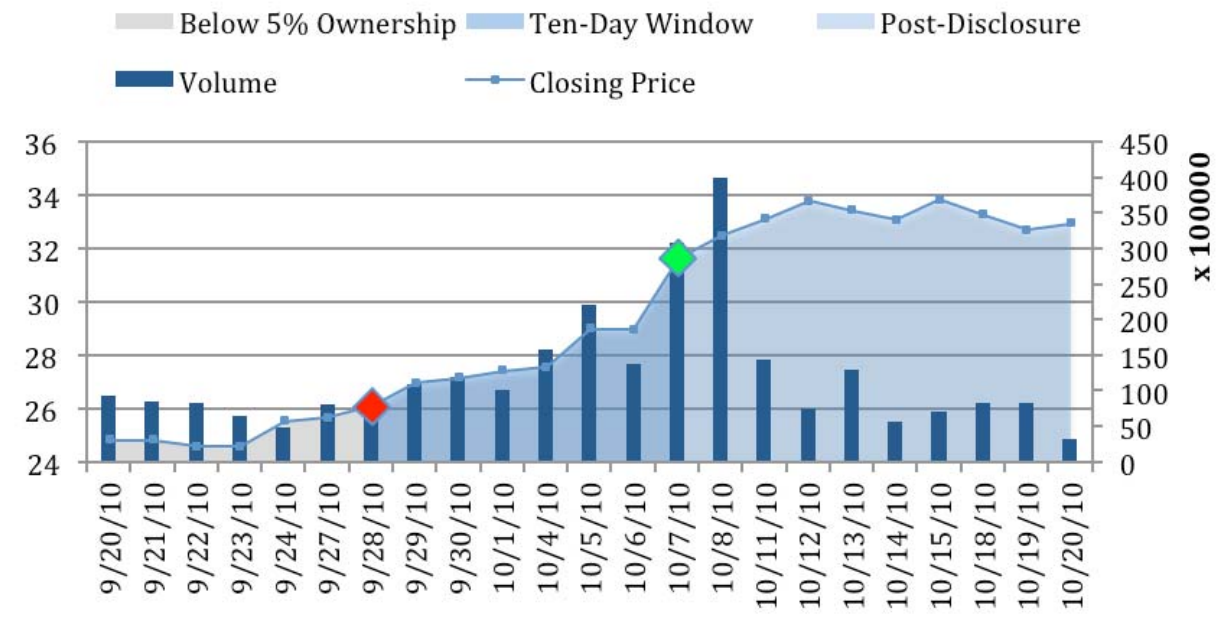

Data Source: Yahoo! Finance. Date Range: 9/20/2010 - 10/20/2010. ${ }^{20}$

This chart shows the closing price of J.C. Penney prior to, during, and following the ten-day window and section 13(d) blockholder disclosure. Pershing Square's announcement occurred following the close of trading on October 7, 2010, as indicated by the green diamond on that day. ${ }^{21}$ Both Pershing Square and Vornado crossed the 5\% threshold on September 28, 2010, as indicated by the red diamond. ${ }^{22}$ The chart demonstrates that the

${ }^{20}$ Yahoo! FinanCe, J. C. Penney Company Inc. (JCP): Historical Prices, http://finance.yahoo.com/q/hp?s=JCP+Historical+Prices (last visited 11/3/2012).

${ }^{21}$ Pershing Square's schedule 13D was filed with the SEC on October 8, 2010 at 9:15 AM. EDGAR Filing Documents: 0000950123-10-092199, Form SC 13D, U.S. SECURITIES AND EXCHANGE COMMISSION (Oct. 8, 2010), http://www.sec.gov/Archives/edgar/data/1166126/000095012310092199/000095012310-092199-index.htm. Vornado Realty Trust's schedule 13D was filed at on October 8, 2010 at 5:10 PM. ED GAR Filing Documents: 0000903423-10-000566, Form SC 13D, U.S. SECURITIES AND EXCHANGE COMMISSION (Oct. 8, 2010), http://www.sec.gov/Archives/edgar/data/899689/000090342310000566/0000903423-10000566-index.htm.

${ }^{22}$ See J.C. Penney Co., Schedule 13D: Pershing Square Capital Management, L.P. (Sep. 28, 2010), available at http://www.sec.gov/Archives/edgar/data/1166126/000095012310092199/y04041sc13d.ht m; J.C. Penney Co., Schedule 13D: Vornado Realty Trust (Sep. 28, 2010), available at 
A PRIVATE ORDERING SOLUTION TO BLOCKHOLDER DisClOSURE

price of J.C. Penney's stock remained well below its post-disclosure high of \$32.49 for much of the ten-day window, permitting these hedge funds to acquire much of their $26.7 \%$ stake at a substantial discount to the postdisclosure price.

A chart of Fortune Brands's stock price demonstrates the same phenomenon: ${ }^{23}$

Figure 2: Fortune Brands Inc. / Beam, Inc. (BEAM)

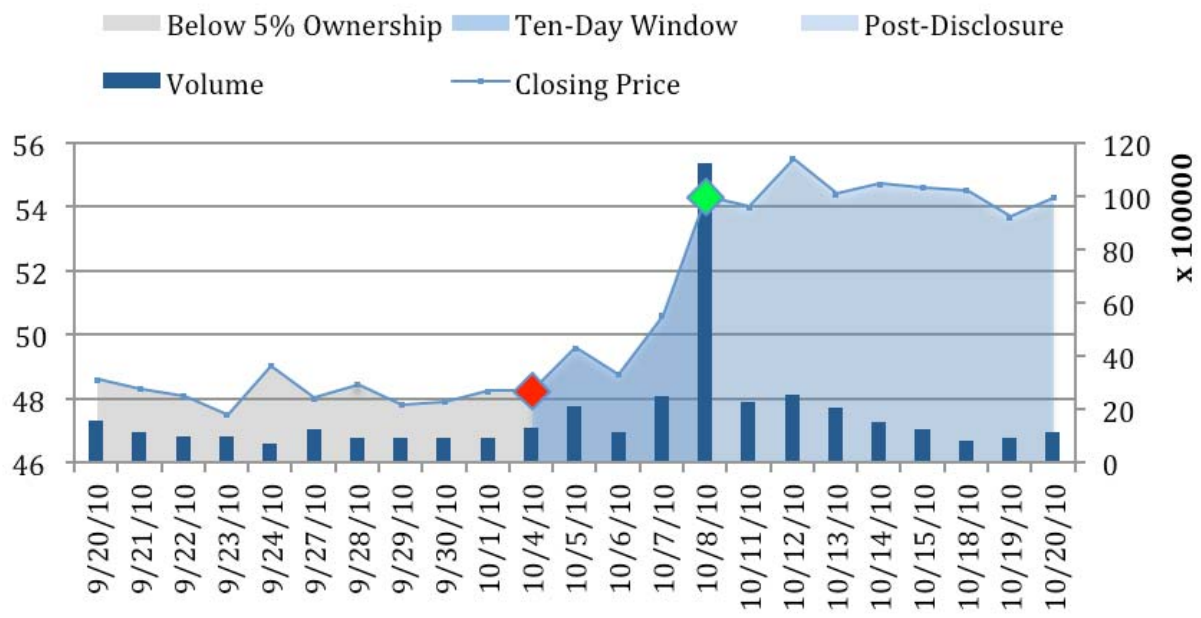

Data Source: Yahoo! Finance. Date Range: 9/20/2010 - 10/20/2010. ${ }^{24}$

As with J.C. Penney, this chart shows the closing price of Fortune Brands Inc. prior to, during, and following the ten-day window and section 13(d) blockholder disclosure. The announcement occurred after the close of trading on October 8, 2010, as indicated by the green diamond on that

http://www.sec.gov/Archives/edgar/data/899689/000090342310000566/vornado13d_100 8.htm.

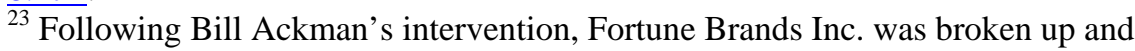
renamed to Beam, Inc. Bruce Schreiner, Fortune Brands Becomes Beam Inc., Sticks To Liquor, BUSINESS WEEK (Oct. 3, 2011), available at http://www.businessweek.com/ap/financialnews/D9Q52TT01.htm.

${ }^{24}$ YAHOO! FinANCE, Beam, Inc. (BEAM), http://finance.yahoo.com/q/hp?s=BEAM+Historical+Prices (last visited 11/3/2012). 
day. ${ }^{25}$ However, Pershing Square did not pass the 5\% threshold until October 4, 2010, as indicated by the red diamond. ${ }^{26}$ Nonetheless, the chart shows that Pershing Square was able to acquire the remainder of its stake at a substantial discount from October $4-7,2010$, as the share price remained well below its post-disclosure level during this period.

The date range for these charts was chosen to demonstrate important aspects of Wachtell Lipton's proposal to reform the blockholder disclosure window. The period prior to crossing the $5 \%$ beneficial ownership threshold - from the left edge of the chart (i.e., September 20, 2010) to the red diamond-would remain untouched by any reform to the blockholder disclosure window. During this period of time, hedge funds would be under no obligation to report because they have not crossed the $5 \%$ threshold. In the debate over reforming the blockholder disclosure window, there is no suggestion to lower the $5 \%$ disclosure threshold. ${ }^{27}$ Indeed, the purchases of the initial $5 \%$ ownership stake by hedge funds prior to crossing the disclosure threshold can be at prices that are a substantial discount to the market prices that follow the initial public announcement of their acquisitions. In J.C. Penney's case, for example, Pershing Square acquired an initial $4.9 \%$ block at an average price of $\$ 20.69$ prior to crossing the 5\% level on September 28, 2010, and Vornado acquired an initial $6.6 \%$ stake in a single call options transaction

${ }^{25}$ Pershing Square's schedule 13D was filed with the SEC on October 8, 2010 at 5:!0 PM. EDGAR Filing Documents: 0000950123-10-092199, Form SC 13D, U.S.

SECURITIES AND EXCHANGE COMMISSION (Oct. 8, 2010), http://www.sec.gov/Archives/edgar/data/789073/000095012310092375/0000950123-10092375-index.htm.

${ }^{26}$ See Fortune Brands, Inc., Schedule 13D: Pershing Square Capital Management, L.P. (Oct. 4, 2010), available at http://www.sec.gov/Archives/edgar/data/789073/000095012310092375/c06741sc13d.ht $\frac{\mathrm{m}}{27}$.

${ }^{\frac{77}{27}}$ In light of the extraordinary profit that hedge funds can obtain prior to crossing the 5\% threshold and the economic analysis infra Part III on the costs and benefits of hedge fund activism, it is possible that the very existence of a minimum disclosure threshold encourages too much hedge fund activism. Yet changing the disclosure threshold for section 13(d) would require congressional action. Accordingly, this Article focuses on the policy debate that is currently being conducted over reforming the section 13(d) filing window by SEC rulemaking action alone under section 929R of the Dodd-Frank Act. 
at an underlying purchase price of $\$ 26.72$ on the same date. ${ }^{28}$ This would have still yielded an impressive profit. If these hedge funds had sold at $\$ 33.30$, the closing price ten days after disclosure, ${ }^{29}$ they would have made a profit of approximately \$147 million and \$102 million on their initial stakes, respectively. ${ }^{30}$ Similarly, Pershing Square bought its initial $4.9 \%$

${ }^{28}$ All of the calculations in this Subsection are on file with the author. The share prices are taken from Item 5(c) of each hedge fund's J.C. Penney schedule 13D filing and exhibits attached thereto. J.C. Penney Co., Schedule 13D: Pershing Square Capital Management (Sep. 28, 2010), available at http://www.sec.gov/Archives/edgar/data/1166126/000095012310092199/y04041sc13d.ht m; J.C. Penney Co., Schedule 13D: Vornado Realty Trust (Sep. 28, 2010), available at http://www.sec.gov/Archives/edgar/data/899689/000090342310000566/vornado13d_100 8.htm. For call options, the "purchase price" is calculated based on intrinsic value, i.e., the sum of the cost of acquiring the option and its strike price, as this represents the minimum price at which the buyer could acquire the underlying shares. Admittedly, calculating profit based on call options' intrinsic value will understate the potential profit because the option itself has value. But the option value is difficult to estimate in these cases, as many were over-the-counter options that lack a market price. Rather than include option value in some cases and not others, this calculation errs on the side of caution and utilizes the intrinsic value alone.

${ }^{29}$ In most cases, hedge funds would not have sold this quickly. The existence of this higher share price reflects investor expectations that the hedge fund activism will yield some type of payoff for shareholders, which presumably takes longer than ten days. (That said, the mere entrance of an activist hedge fund could prompt certain reforms that shareholders might consider beneficial.) As discussed below, researchers who believe the efficient markets hypothesis often rely on event-day studies which look to share price returns in a certain post-event window, e.g., 10 days, to determine whether the event creates long-term shareholder value. See discussion infra Section III.A.1. While I criticize the efficient markets hypothesis, see discussion infra Section III.A.2, it is rational to use such a window to calculate a hedge fund's hypothetical profit. Even if this higher share price does not reflect the creation of fundamental value because markets are inefficient, hedge funds could still "sell into" this wave and dispose of the initial 5\%. Moreover, they could still obtain this profit on the remainder of their shares if the share price remained at this level several months later, if, for example, the market had not yet internalized the damage that excessive activism would cause. For a discussion of markets' temporal inefficiency, see discussion infra Section III.A.2.

${ }^{30}$ This is computed by subtracting the total purchase price each hedge fund paid prior to and contemporaneously with crossing the $5 \%$ threshold from the product of the number of shares acquired during this period and a closing price of \$33.30 on October 18, 2010. The exact trading data utilized for this computation is included in the schedule 13D filings and the calculations are on file with the author. See J.C. Penney Co., Schedule 
of Fortune Brands at an approximate average price of $\$ 42.52 .{ }^{31}$ If it had sold at the 10-day post-disclosure closing price of $\$ 54.51,{ }^{32}$ it would have made a profit of approximately $\$ 86.5$ million. ${ }^{33}$ While the latter figure is less than the former two, ${ }^{34}$ both reflect a sizeable payoff for these activist hedge funds for acquiring the initial $5 \%$ stake at significant discount to the post-disclosure price.

Again, this payoff would remain untouched by Wachtell Lipton's proposal. Rather, the petition focuses on the additional profit that would result from stealthily acquiring additional shares during the ten-day disclosure window. To illustrate how much is at stake, the average price of the J.C. Penney shares acquired by Pershing Square and Vornado from September 28, 2010 to October 7, 2010 was \$29.27 and \$27.39, respectively. If Pershing Square and Vornado had sold at the ten-day post-disclosure closing price of $\$ 33.30$, they would have made a profit of approximately $\$ 193$ million and $\$ 43$ million on the stake that they acquired during the 10-day window, respectively. ${ }^{35}$ Similarly, Pershing

13D: Pershing Square Capital Management, supra note 22; J.C. Penney Co., Schedule 13D: Vornado Realty Trust, supra note 22.

${ }^{31}$ The calculations are on file with the author.

${ }^{32}$ This price has been adjusted for stock splits and dividends.

${ }^{33}$ As with J.C. Penney, the computation utilizes the actual purchase price included in the trading data attached to Pershing Square's schedule 13D filing. See Fortune Brands, Inc., Schedule 13D: Pershing Square Capital Management, L.P., supra note 25.

${ }^{34}$ This may have been because the hedge funds took a smaller stake in Fortune Brands than J.C. Penney ( $11 \%$ as opposed to $27 \%$ ), making it less certain that they could bring about the type of improvements that would increase shareholder value (at least over the short-term).

${ }^{35}$ The calculations are on file with the author. As with the initial period profit, this utilizes the actual trading data reported on the schedule 13D filings. The computation subtracts the total purchase price each hedge fund paid subsequent to crossing the $5 \%$ threshold (and prior to the 13D filing) from the product of the total number of shares and the closing price of $\$ 33.30$ on October 18, 2010. The computation treats cash-settled total return swaps as common stock for purposes of this calculation, since the hedge funds the long party would be able to realize their potential profit by unwinding the swaps and acquiring the underlying shares. One might criticize the use of the $\$ 33.30$ closing price as unrealistic because the hedge funds could not sell $21 \%$ of the stock instantly without moving the price down. If it is a rough approximation, however, of investors' anticipation of value creation-a proposition this Article accepts with respect to short-term expectations - the price would not fall significantly upon liquidation. 
Square acquired the remainder of its $10.9 \%$ stake in Fortune Brands at the average price of $\$ 49.80$ during the period from October 4, 2010 to October 7,2010 . Had it sold at the ten-day post disclosure price of $\$ 54.51$, Pershing Square would have made a profit of approximately \$51.6 million on the stake it acquired during the delayed disclosure period. ${ }^{36}$ This additional profit would be eliminated under Wachtell Lipton's proposal.

Finally, shareholder activists continue to exploit the delayed disclosure window to acquire large blocks of ownership at a substantial discount to the post-disclosure market price. Most recently, in October 2012, Carl Ichan stealthily acquired $9.98 \%$ of Netflix at an average price of $\$ 60.01$ after crossing the 5\% threshold. ${ }^{37}$ Had he sold at the ten-day post-disclosure price of $\$ 78.19$, Ichan would have made a profit of approximately \$52 million on the stake he acquired during the delayed disclosure period alone.

\section{B. Legislative History: The Williams Act of 1968 and Section 929R of the Dodd-Frank Act of 2010}

The legislative history of the ten-day window suggests that Congress did not intend for it to be exploited through stealth accumulations. The ten-day window was enacted by the Williams Act of 1968, which arose out of a concern with the increasing use of cash tender offers to effect hostile takeovers. ${ }^{38}$ The legislation initially was introduced in the $111^{\text {th }}$ Congress by Senator Williams, who condemned "the cloak of

Accordingly, these reflect a form of hypothetical profit. It is also a useful measure of the injury to trading counterparties who could have sold at the $\$ 33.30$ closing price. See discussion infra Section IV.C.2.

${ }^{36}$ The calculations are on file with the author, and utilize the same methodology as the prior profit computations.

${ }^{37}$ See Greg Bensinger \& Ian Sherr, Icahn Takes Stake in Netflix, WALL ST. J. (Nov. 1, 2012), http://online.wsj.com/article/SB10001424052970203707604578091032309599550.html.

${ }^{38}$ For a summary of the legislative history of the Williams Act of 1968, see Andrew E. Nagel, Andrew N. Vollmer \& Paul R.Q. Wolfson, The Williams Act: A Truly "Modern" Assessment, HARV. L. SCH. FORUM ON CORP. GOVERNANCE \& FIN. REG., at *5-7 (Oct. 22, 2011), http://blogs.law.harvard.edu/corpgov/files/2011/10/The-Williams-Act-ATruly-Modern-Assessment.pdf. 
secrecy under which" a corporate raider is "permitted to operate while obtaining the shares needed to put him on the road to successful capture of a company.,"39

As originally proposed, the bill would have required prior notice to the Securities and Exchange Commission twenty days before making a cash tender for over five percent of the a class of outstanding shares as well as disclosure upon acquiring five percent beneficial ownership through open market purchases. ${ }^{40}$ The prior notice requirement led to strong opposition from the SEC, which argued that a five-day postacquisition notification window would be "less burdensome" and more realistic in situations where prior notice might be impossible. ${ }^{41}$

Senator Williams subsequently introduced a modified bill to require disclosure within seven days of acquiring ten percent beneficial ownership, ${ }^{42}$ followed by another amendment to lengthen the disclosure window to ten days. ${ }^{43}$ These were the substantive terms that were ultimately enacted as the Williams Act of 1968 . $^{44}$ Two years later, the disclosure threshold was lowered to five percent. ${ }^{45}$ In Senator Williams's words, "Stock holdings of between 5 and 10 percent in [large public] companies are in many instances a controlling interest. Here the need for the full disclosure requirements of the Securities Exchange Act are necessary for adequate investor protection." ${ }^{\text {46 }}$ This is the disclosure requirement that applies today. ${ }^{47}$

The ten-day blockholder disclosure window remained undisturbed for thirty years. In 2010, Congress passed the Dodd-Frank Wall Street Reform and Consumer Protection Act, which provided in section 929R:

${ }^{39} 111$ Cong. Rec. 28258 (Oct. 22, 1965).

${ }^{40} I d$.; S. 2731, §2, $89^{\text {th }}$ Cong. (1965).

${ }^{41} 112$ Cong. Rec. 19004 (Aug. 11, 1966) ("Indeed, we envision some types of situations in which compliance with an advance notice requirement would be impossible, such as acquisitions by inheritance or by gift of which the recipient had no advance notice.”).

42113 Cong. Rec. 856 (Jan. 18, 1967); S. 510, § 1, $90^{\text {th }}$ Cong. (1967).

43113 Cong. Rec. 24664 (Aug. 30, 1967).

${ }^{44}$ Pub. L. No. 90-439, 82 Stat. 454 (1968).

${ }^{45}$ Pub. L. No. 91-567, 84 Stat. 1497 (1970).

${ }^{46} 116$ Cong. Rec. 3023 (1970).

${ }^{47} 15$ U.S.C.A $\S 78 \mathrm{~m}(\mathrm{~d})(1)$. 
A Private ORdering SOLUTION TO BlOCKHOLDER DisClOSURE

(a) BENEFICIAL OWNERSHIP REPORTING.--Section 13 of the Securities Exchange Act of 1934 (15 U.S.C. 78m) is amended- (1) in subsection (d)(1) - (A) by inserting after "within ten days after such acquisition"' the following: " or within such shorter time as the Commission may establish by rule,,48

This language was found in the initial draft of the Investor Protection Act of 2009 submitted by House Committee on Financial Services. ${ }^{49}$ In the "section-by-section analysis of the legislation," the Committee explained the rationale behind the inclusion of this provision:

Section 105. Beneficial ownership and short swing profit reporting

This section provides the SEC with the authority to adopt rules to shorten reporting timeframes and help the markets receive more timely information concerning substantial ownership interests in issuers. This change is important for purposes of obtaining more accurate pricing of listed securities. $^{50}$

It thus appears that the Committee was concerned with the potential for mispricing during the ten-day window. Indeed, as the example of J.C. Penney and Fortune Brands demonstrates, the difference between the average price during the ten-day window and the price following disclosure can be substantial. In the case of J.C. Penney, exploiting this difference led to over \$200 million in profit for two activist hedge funds. The Committee's intent seems plainly directed to drawing the SEC's attention to the potential exploitation of this pricing differential.

The Dodd-Frank Act also displayed concern for the growing use of synthetic instruments such as cash-settled total return swaps, which permit the rapid accumulation of equity ownership via indirect means with a

${ }^{48}$ Dodd-Frank Wall Street Reform and Consumer Protection Act, Public Law 111-203, 124 Stat. 1866, § 929R (Jul. 21, 2010).

${ }^{49}$ H. Rep. No. 111-687, at 6 (2010).

${ }^{50} \mathrm{Id}$. at 76 . 
minimal impact on share prices. ${ }^{51}$ These have been used by hedge funds to acquire large blocks of shares at minimal cost, ${ }^{52}$ and were utilized by Pershing Square in its stealth accumulation of J.C. Penney shares. ${ }^{53}$ Section 766(e) of the Dodd-Frank Act specifically authorizes the SEC to include "security-based swaps" within the definition of beneficial ownership under section 13(d). ${ }^{54}$ However, such swaps constitute beneficial ownership only if the SEC so designates:

[A] person shall be deemed to acquire beneficial ownership of an equity security based on the purchase or sale of a security-based swap, only to the extent that the Commission, by rule, determines after consultation with the prudential regulators and the Secretary of the Treasury, that the purchase or sale of the security-based swap . . . provides incidents of ownership comparable to direct ownership of the equity security, and that it is necessary to achieve the purposes of this section that the purchase or sale of the security-based swaps, or class of security-based swap, be deemed the acquisition of beneficial ownership of the equity security. ${ }^{55}$

\footnotetext{
${ }^{51}$ Cash-settled total return swaps are a form of equity derivatives that transfer the entire credit risk and market risk of an asset to the holder without actually acquiring ownership of the underlying security. See, e.g., Patricia A. Koval, Torys On MERgERS AND ACQUISITIONS: USE OF DERIVATIVES BY SHAREHOLDER ACTIVISTS (2011), available at http://www.torys.com/Publications/Documents/Publication\%20PDFs/MA2011-3.pdf (describing the use of these swaps by hedge fund activists to acquire exposure to the underlying securities without constituting beneficial ownership and explaining how they may be easily converted to voting securities).

${ }^{52}$ See, e.g., Andrew Ross Sorkin, Dealbook, Big Investors Appear Out of Thin Air, N.Y. Times (Nov. 1, 2010) ("The use of derivatives to create stealth positions is even more worrisome.”).

${ }^{53}$ See J.C. Penney Co., Schedule 13D: Pershing Square Capital Management, supra note 22; Maxwell Murphy, Deal Journal, How Bill Ackman Stalked J.C. Penney, WALL ST. J., October 8, 2010 (mentioning Bill Ackman's use of cash-settled total return swaps).

${ }^{54} 15$ U.S.C.A § 78m; Dodd-Frank Wall Street Reform and Consumer Protection Act, § 766(e).

${ }^{55} I d$. (emphasis added).
} 
In a recent decision, the Second Circuit left unresolved the question of whether cash-settled total return equity swaps constitute beneficial ownership under the existing section 13(d) and rule $13 \mathrm{~d}-3 .{ }^{56}$ The potential for rapid stealth accumulations during the ten-day window in light of the increasing use of cashsettled total-return swaps led to a vibrant academic and policy debate as discussed in the next Section.

\section{The Academic and Policy Debate Over Shortening the Ten-Day Window}

The current debate surrounding shortening the disclosure window began with a rulemaking petition submitted by Wachtell Lipton to the Securities and Exchange Commission. ${ }^{57}$ Wachtell Lipton argued that the ten-day window contravenes the purpose of the Williams Act by permitting rapid stealth acquisitions of quasi-controlling blocks, which was precisely what Congress sought to prohibit by enacting the blockholder disclosure reporting requirements. ${ }^{58}$ Moreover, Wachtell Lipton claimed, the recent examples of J.C. Penney and Fortune Brands vividly demonstrate that the ten-day window is no longer suited to an age where large blocks of shares may be rapidly accumulated, particularly when synthetic ownership, e.g. derivatives, permit even faster accumulation of net long equity positions.

In response, Professors Lucian A. Bebchuk and Robert J. Jackson criticized Wachtell Lipton's petition and advocated that the current ten-

\footnotetext{
${ }^{56}$ CSX Corp. v. Children's Inv. Fund Management (UK) LLP, 654 F.3d 276, 284 (2d Cir. 2011) (remanding to the district court on different grounds). But see id. at 301 (Winter, J., concurring) ("In the absence of some other agreement governing the disposition of shares purchased to hedge a swap position, merely having a long position in a cash-settled total-return equity swap does not constitute having the power, directly or indirectly, to direct the disposition of shares that a counterparty purchases to hedge its swap positions, and thus does not constitute having "investment power" for purposes of Rule 13d-3(a).”).

${ }^{57}$ Letter from Wachtell, Lipton, Rosen \& Katz to Elizabeth M. Murphy, supra note 16.

${ }^{58} I d$. at $* 2$.

${ }^{59} I d$. at *6-8.
} 
day period remain unchanged. ${ }^{60}$ Bebchuk and Jackson claim that the SEC should evaluate the suitability of the blockholder disclosure window in light of academic research regarding the beneficial role of activist investors in public companies. ${ }^{61}$ They discuss the empirical financial literature finding a correlation between hedge fund activism and shareholder value ${ }^{62}$ and argue that the ten-day window functions as a form of compensation to blockholders for monitoring and disciplining management. They argue that such compensation is essential because as non-controlling shareholders activist blockholders only share pro rata in the benefits of their activism. ${ }^{63}$

This Article advocates a balanced approach to resolving this debate. Wachtell Lipton correctly points out that the purpose of the disclosure requirements in the Williams Act was to prevent stealth acquisitions. Yet while the Dodd-Frank Act explicitly empowered the Securities and Exchange Commission to shorten the disclosure window, the Act did not limit the SEC's discretion to conforming to the historical purpose of the Williams Act. As a matter of positive law, agency rulemaking is more than a historical inquiry into congressional intent. Administrative agencies are obligated to consider the costs and benefits of various policy alternatives and enact rules that further the public interest.

More fundamentally, Wachtell Lipton's descriptive claim (what "is") does not imply a normative outcome (what "should be”). Even under the extreme assumption that the SEC must, as a matter of positive law,

\footnotetext{
${ }^{60}$ Lucian A. Bebchuk \& Robert J. Jackson Jr., The Law and Economics of Blockholder Disclosure, 2 HARV. BUS. L. REV. 39 (2012), available at http://papers.ssrn.com/sol3/papers.cfm?abstract_id=1884226. In a recent reply, four partners from Wachtell Lipton reiterate their argument that Bebchuk \& Jackson’s costbenefit analysis is flawed because it is "missing" "any explanation of how their position their conception of how the Section 13(d) reporting rules should operate - is consistent with the clear purpose of the statute.” Adam O. Emmerich, Theodore N. Mirvis, Eric S. Robinson \& William Savitt, Fair Markets and Fair Disclosure: Some Thoughts on the Law and Economics of Blockholder Disclosure, and the Use and Abuse of Shareholder Power, (Columb. L. \& Econ. Working Paper No. 428, Aug. 27, 2012), available at http://papers.ssrn.com/sol3/papers.cfm?abstract id=2138945.

${ }^{61} I d$. at $* 12$.

${ }^{62}$ See discussion infra Section III.A.

${ }^{63}$ Bebchuk \& Jackson, supra note 21, at *16-19.
} 
shorten the disclosure window because technological innovations render the letter of the law no longer effective at fulfilling its purpose, this does not imply that a shorter disclosure window necessarily would be in firms' or society's best interest. Put differently, Congress may have erred. Blockholder disclosure ultimately may not be socially beneficial. Apart from the doctrinal question of what the SEC is bound by law to consider as an administrative agency, it is essential to address the normative question of what is best for society.

Answering this normative question requires finding a justification external to the descriptive content of the law itself. The law-andeconomics methodology prevalent in corporate and securities law generally assumes that promoting Kaldor-Hicks efficiency-i.e., producing gains to society that exceed losses - should be the normative goal that the law advances. ${ }^{64}$ A proposal to shorten the blockholder disclosure window should be justified through economic analysis, not solely by pointing to the descriptive content of legislative history.

To their credit, Bebchuk and Jackson cite to economic and financial research to make a normative claim that the ten-day window is better for society than a shorter alternative. ${ }^{65}$ Yet they look solely at the benefits of hedge fund activism without considering the costs that activism - particularly excessive activism—-may impose. ${ }^{66}$ It is impossible to compare the ten-day window to a shorter period without evaluating the costs and benefits of both alternatives.

As described in Sections III.B and III.C, if the current regime encourages excessive activism, there are two potential sources of costs: (1) harm to target firms in the form of managerial short-termism, which may not be reflected in empirical event-day studies if markets are inefficient; and (2) social externalities such as chilling effects among market participants resulting from trading on asymmetric information and the non-economic harm of depriving trading partners of autonomy. Without

\footnotetext{
${ }^{64}$ See generally Richard A. Posner, The Ethical and Political Basis of the Efficiency Norm in Common Law Adjudication, 8 HofsTRA L. REV. 487, 488 (1979).

${ }^{65}$ Bebchuk \& Jackson, supra note 21, at *12 (citing studies).

${ }^{66}$ Interestingly, when Bebchuk \& Jackson discuss "costs," they are referring to the potential costs of Wachtell Lipton's proposal, not to the social cost imposed by the status quo of ten-day delayed disclosure on firms and society. $I d$. at *17.
} 
A PRIVATE ORDERING SOLUTION TO BLOCKHOLDER DisClOSURE

discussing these potential costs, the net social utility resulting from the ten-day window remains unknown, even if empirical studies suggest that hedge fund activism does bring value to firms under certain conditions.

\section{THE COSTS AND BENEFITS OF DELAYEd BLOCKHOLDER DISCLOSURE}

This Part discusses the costs and benefits of delayed blockholder disclosure. Hedge fund activism may create value by monitoring and disciplining management, but these benefits must be balanced against the potential for inducing short-termism among target firms. Moreover, delayed blockholder disclosure imposes economic and non-economic costs on society that must be considered as well.

\section{A. Creating Value by Monitoring and Disciplining Management}

\section{Agency Costs, Hedge Fund Activism and Shareholder Value}

Many scholars consider hedge fund activism beneficial because large blockholders have natural incentives to monitor and discipline management, which can reduce the principal/agent problem inherent in corporate governance. Ever since Jensen \& Meckling's seminal discussion of agency costs resulting from the separation of ownership from control, ${ }^{67}$ corporate governance scholars have sought ways to encourage monitoring incentives in firms with disparate ownership such as publicly traded companies. ${ }^{68}$ Many have pointed to the threat of a hostile takeover as an effective means of disciplining management, noting that "[e]conomic analysis and evidence indicate that the market for corporate control is benefitting shareholders, society, and the corporate form of

\footnotetext{
${ }^{67}$ Michael C. Jensen \& William H. Meckling, Theory of the Firm: Managerial Behavior, Agency Costs And Ownership Structure, 3 J. Fin. ECON. 305, 308 (1976).

${ }^{68}$ Leading studies on this problem include Eugene F. Fama, Agency Problems and the Theory of the Firm, 88 J. POL. ECON. 288 (1980); Eugene F. Fama \& Michael C. Jensen, Separation of Ownership and Control, 26 J.L. \& ECON. 301 (1983).
} 
organization.”99 The basic theory is that unhappy shareholders can sell their shares to a hostile bidder and thereby effect a change of management once that bidder obtains a controlling block of stock. Empirical event-day studies have shown support for the hypothesis that hostile bidders create value for target firms. ${ }^{70}$

There are many similarities between takeovers and hedge fund activism, most notably that blockholders have a greater incentive than other shareholders to monitor management in order to maximize the value of their shares. ${ }^{71}$ However, regulatory and structural constraints such as conflicts of interests limit the effectiveness of activism by traditional institutional investors like mutual funds, e.g., when the target firm's management is a client of these funds' parent financial institutions. ${ }^{72}$ Recently, hedge funds have stepped into this void, largely free of these constraints and with compensation structures that make them able to "benefit directly and substantially from achieving high absolute returns."73

Consistent with this hypothesis, empirical studies have found a correlation between announcements of hedge fund activism and stock price increases. In a recent study, Alon Brav, Wei Jiang, Frank Partnoy

${ }^{69}$ Michael C. Jensen, Takeovers: Their Causes and Consequences, 2 J. ECON. PERSPECTIVES 21 (1988); see also FrANK EASTERBROOK \& DANIEL FisCHEL, THE ECONOMIC STRUCTURE OF CORPORATE LAW (1996); Michael C. Jensen, Agency Costs of Free Cash Flow, Corporate Finance, and Takeovers, 76 Am. ECon. REv. 323 (1986).

${ }^{70}$ Clifford G. Holderness \& Dennis P. Sheehan, Raiders or Saviors? The Evidence on Six Controversial Investors, 14 J. Fin. ECON. 555 (1985).

${ }^{71}$ For a comprehensive discussion, see Marcel Kahan \& Edward B. Rock, Hedge Funds in Corporate Governance and Corporate Control, 155 U. PA. L. REv. 1021, 1048-69 (2006).

${ }^{72}$ Id. at 1048 (citing Bernard S. Black, Agents Watching Agents: The Promise of Institutional Investor Voice, 39 UCLA L. REV. 811, 813-816 (1992); Edward B. Rock, The Logic and (Uncertain) Significance of Institutional Shareholder Activism, 79 GEO. L.J. 445 (1991)); see also Stuart Gillan \& Laura T. Starks, Corporate Governance Proposals And Shareholder Activism: The Role Of Institutional Investors, 57 J. Fin. ECON. 275 (2000); see generally Anat R. Admati et al., Large Shareholder Activism, Risk Sharing, and Financial Market Equilibrium, 102 J. POL. ECON. 1097 (1994); Bernard S. Black, Shareholder Passivity Reexamined, 89 MicH. L. REV. 520 (1990); Ronald J. Gilson \& Reinier Kraakman, Reinventing the Outside Director: An Agenda for Institutional Investors, 43 STAN L. REV. 863 (1991).

${ }^{73}$ Kahan \& Rock, supra note 38, at 1065. 
and Randall Thomas found abnormal returns of 7\% from 13D filings revealing activist hedge fund investments using an event-day methodology with a window of $+/-20$ days. $^{74}$ This study utilized an original dataset and contains several interesting findings, including that a median maximum ownership stake of $9.1 \%$ and a $95^{\text {th }}$ percentile ownership stake of $31.5 \%$, suggesting that activist hedge funds are not seeking to acquire their targets. ${ }^{75}$ Similarly, April Klein and Emanuel Zur find that targets of activist investors (including hedge funds and other types of private investors) "earn $10.2 \%$ average abnormal stock returns during the period surrounding the initial Schedule 13D."76 Both of these studies find that abnormal results hold in the one-year period following the schedule 13D announcement. ${ }^{77}$ Other studies show indirect benefits from outside blockholder activism. ${ }^{78}$

${ }^{74}$ Alon Brav et al., Hedge Fund Activism, Corporate Governance, and Firm Performance, 63 J. FIN. 1729, 1730 (2008); see also Alon Brav et al., Hedge Fund Activism: A Review, 4 FOUNDATIONS AND TRENDS IN FINANCE 185 (2009).

${ }^{75} \mathrm{Id}$. at 1732.

${ }^{76}$ April Klein \& Emanuel Zur, Entrepreneurial Shareholder Activism: Hedge Funds and Other Private Investors, 64 J. FIN. 187, 188 (2009).

${ }^{77}$ Brav et al., supra note 74, at 1730-31; Klein \& Zur, supra note 76, at 188 . Brav et al. maintain an updated table reporting long-term average returns for targets of hedge fund activism and claim that "the evidence clearly refutes the market over-reaction hypothesis and supports the hypothesis that hedge fund activism creates value for shareholders." Brav et al., Hedge Fund Activism: Updated Tables and Figures, at *10, available at http://faculty.fuqua.duke.edu/\%7Ebrav/HFactivism_March_2012.pdf (last visited Sep. 16, 2012). However, Brav et al. utilize a calendar-time portfolio holding methodology. Id. ("We report regression estimates and t-statistics from equal- and value-weighted calendar-time portfolio regressions.”). The use of a calendar-time portfolio method has been criticized because "in nonrandom samples, the calendar-time portfolio methods often yield misspecified test statistics.” John D. Lyon, Brad M. Barber \& Chih-Ling Tsai, Improved Methods for Tests of Long-Run Abnormal Stock Returns, 54 J. FIN. 165, 193 (1999). The dataset utilized by Brav et al. is plainly a nonrandom sample, as it consists of " 236 activist hedge funds and 1,059 hedge fund-target pairs for the period 2001 to 2006, involving 882 unique target companies.” Brav et al., supra note 74, at 1739. Accordingly, long-run inference based on calendar-time portfolio methods should be viewed with suspicion.

${ }^{78}$ Bebchuk \& Jackson, supra note 21, at *13-14 (citing Marianne Bertrand \& Sendhil Mullainathan, Are CEOs Rewarded for Luck? The Ones Without Principals Are, 116 Q. J. ECON. 901, 903 (2001); Lucian A. Bebchuk et al., Lucky CEOs and Lucky Directors, 65 J. FIN. 2363, 2365 (2010); James A. Brickley et al., Ownership Structure and Voting on 
While it is not without controversy, ${ }^{79}$ the use of event-day studies is prevalent in corporate governance studies. ${ }^{80}$ As two prominent scholars put it, "Event studies, relying on the efficient markets hypothesis, assume that public information is incorporated into stock prices and that stock prices change when new information is revealed." ${ }^{\prime \prime 1}$ The efficient markets hypothesis implies that the positive abnormal returns found in the studies by Brav et al. and Klein and Zur reflect the creation of fundamental value. ${ }^{82}$ The market's response to hedge fund activism - bidding up the price of target firm shares-is efficient. It is incorporating all available public information and concluding that hedge fund activism will improve the future cash flow of shareholders of target firms. Brav et al. and Klein and Zur generally assume that the efficient markets hypothesis is accurate, as indicated by their conclusion that these abnormal returns unequivocally establish that hedge fund activism creates shareholder value. ${ }^{83}$

\section{Inefficient Markets and Long-Term Value Creation}

The problem with relying on event-day studies as conclusive evidence that hedge funds create shareholder value is that there is a vast

Antitakeover Amendments, 20 J. Fin. ECON. 267 (1988); Anil Shivdasani, Board Composition, Ownership Structure, and Hostile Takeovers, 16 J. ACCT. \& ECON. 167 (1993); Anup Agrawal \& Tareque Nasser, Blockholders on Boards and CEO Compensation, Turnover and Firm Valuation (Nov. 27, 2011), available at http://bama.ua.edu/ aagrawal/IDB-CEO.pdf (unpublished manuscript)).

${ }^{79}$ See infra Subsection III.B.2.

${ }^{80}$ See Sanjai Bhagat \& Roberta Romano, Event Studies and the Law: Part II: Empirical Studies of Corporate Law, 4 AM. L. \& ECON. REV. 380 (2002).

${ }^{81} I d$. at 398.

${ }^{82}$ For a traditional overview of the efficient markets hypothesis from one of its most ardent defenders, see Eugene F. Fama, Efficient Capital Markets: II, 46 J. FIN. 1575 (1991); Eugene F. Fama, Efficient Capital Markets: A Review of Theory and Empirical Work, 25 J. FIN. 383 (1970).

${ }^{83}$ Brav et al., supra note 74, at 1732 ("Our findings have important implications for the policy debate about hedge fund activism. . . . our results suggest that activist hedge funds are not short-term holders. Activists also appear to generate substantial value for target firm shareholders.”); Klein \& Zur, supra note 76, at 192 (“Generally, a firm’s stock price increases around the 13D filing date that identifies a new blockholder, indicating that the market interprets this event as value increasing."). 
body of behavioral finance literature that calls the efficient market hypothesis into question. ${ }^{84}$ This research began with drawing attention to empirical anomalies in the data utilized to support the efficient markets hypothesis in the traditional studies. ${ }^{85}$ Behavioral finance scholars found evidence supporting short-term momentum and "feedback," the tendency for asset prices to form a bubble based on ever-increasing expectations of higher prices, only to come crashing down thereafter. ${ }^{86}$ Theoretical models were developed to demonstrate the limitations of arbitrage to correct these anomalies as predicted by the efficient markets hypothesis, and these models were supported by empirical studies. ${ }^{87}$ The asset bubbles of the late 1990s and 2000s in technology stocks and the housing market led to a rejection of the efficient markets hypothesis yet again. ${ }^{88}$

${ }^{84}$ For an overview of the behavioral finance criticism of the efficient markets hypothesis, see Robert J. Shiller, From Efficient Markets Theory to Behavioral Finance, 17 J. ECON. PERSPECTIVES 83 (2003).

${ }^{85}$ See id. at 84 (discussing the empirical anomalies in Eugene F. Fama, Efficient Capital Markets: A Review of Theory and Empirical Work, 25 J. FIN. 383 (1970)); Lawrence H. Summers, Does the Stock Market Rationally Reflect Fundamental Values?, 41 J. FIN. 591 (1986).

${ }^{86}$ E.g., Werner F. M. De Bondt \& Richard H. Thaler, Does the Stock Market Overreact?, 40 J. Fin. 793 (1985); Narasimhan Jegadeesh \& Sheridan Titman, Returns to Buying Winners and Selling Losers: Implications for Stock Market Efficiency, 48 J. FiN. 65 (1993). See generally Shiller, supra note 84, at 96.

${ }^{87}$ E.g., Nicholas Barberis \& Andrei Shleifer, Asset Pricing Model with Stochastic Consumption and Investment Opportunities, 7 J. FIN. ECON. 265 (2000); J. Bradford De Long, Andrei Shleifer, Lawrence H. Summers \& Robert J. Waldmann, Noise Trader Risk in Financial Markets, 98 J. PoL. ECON. 703 (1990); William N. Goetzmann \& Massimo Massa, Daily Momentum And Contrarian Behavior Of Index Fund Investors, 37 J. FIN. \& QUANT. ANALYSIS 375 (2002). See generally Shiller, supra note 84, at 96-97.

${ }^{88}$ E.g., RoBERT J. SCHILLER, IRRATIONAL EXUBERANCE (2000); Paul Krugman, How Did Economists Get It So Wrong?, N.Y. TIMES (Sep. 2, 2009), http://www.nytimes.com/2009/09/06/magazine/06Economic-t.html. Paul Krugman summed it up nicely: "In a 2007 interview, Eugene Fama, the father of the efficientmarket hypothesis, declared that 'the word 'bubble' drives me nuts,' and went on to explain why we can trust the housing market . . . In short, the belief in efficient financial markets blinded many if not most economists to the emergence of the biggest financial bubble in history. And efficient-market theory also played a significant role in inflating that bubble in the first place.” Krugman, supra. See also Geoffrey Hodgson, Reforming Economics after the Financial Crisis, 2 GLOBAL POLICY 190 (May 2011). 
These developments in behavioral finance suggest that the empirical results championed in support of the notion that hedge fund activism creates shareholder value should be viewed with suspicion. Increases in target firm share prices upon schedule 13D announcements may be irrational rather than reflecting increased fundamental value. Purchasers may be overly optimistic regarding the long-term benefits of hedge fund activism or anticipate that counterparties in future transactions will be overly optimistic and pay more than the fundamental value of these shares. In the latter case, bidding up the price of the stock would be rational for current purchasers who anticipate an irrational overpayment by subsequent acquirers. Indeed, empirical studies have found that investors systematically overvalue takeover targets. ${ }^{89}$ An intertemporal transfer payment from future to current shareholders does not reflect an increase in fundamental value.

Incidentally, a schedule 13D filing signals that it is more likely that a firm will undergo a takeover or other change-of-control transaction where a control premium would be paid. Filing a schedule $13 D$ disclosure rather than a schedule $13 G$ disclosure implies that the purchaser has the "purpose" or "effect" of "changing or influencing the control of the issuer." increased likelihood of a control premium payoff likely explains much of the share price bounce. ${ }^{91}$ But this sheds no light on whether hedge fund activism creates fundamental value for target firms over the long-term.

${ }^{89}$ E.g., James S. Ang \& Yingmei Cheng, Direct Evidence On The Market-Driven Acquisition Theory, 29 J. Fin. ReSEARCH 199 (2006); Ming Dong et al., Does Investor Misvaluation Drive the Takeover Market?, 61 J. FIN. 725 (2006); Andrei Shleifer \& Robert W. Vishny, Stock Market Driven Acquisitions, 70 J. FIN. Econ. 295 (2003).

${ }^{90} 17$ C.F.R. § $240.13 d-1(c)(1)$. Rule 13d-1 permits filing a schedule $13 \mathrm{G}$ if the acquirer "[h] as not acquired the securities with any purpose, or with the effect, of changing or influencing the control of the issuer, or in connection with or as a participant in any transaction having that purpose or effect ... other than activities solely in connection with a nomination under § 240.14a-11.” Id.

${ }^{91}$ Cf. Adam O. Emmerich, et al., supra note 53, at *10 (“[A]ctivist 13D filers often agitate for some corporate change - for example, a sale of the company or recapitalization - that may be expected to have a short-term, positive effect on a company's stock price.”); see also Andrei Shleifer \& Robert W. Vishny, Large Shareholders and Corporate Control, 94 J. Pol. ECON. 461 (1986) (discussing the dynamics of large blockholders and the likelihood of a change-of-control). 
More fundamentally, a balanced approach to evaluating the optimality of the blockholder disclosure window requires considering whether hedge fund activism always benefits target firms. Even if hedge fund intervention sometimes creates value, there might be an aggregate level of activism that on balance does more harm than good. As discussed in the next Section, the potential for hedge fund activism to induce shorttermism suggests that it may not always be beneficial.

\section{B. Destroying Value Through Short-Termism: A Summary of the Management and Accounting Research}

Largely missing from the legal debate over shortening the blockholder disclosure window is the body of management and accounting research that demonstrates that short-termism is a very real problem faced by firms today. The legal literature has recognized short-termism as a possibility: a well-known law review article on hedge fund activism identified short-termism as the only "potentially serious problem” that might require regulatory redress but concluded that "a sufficient case for legal intervention has not been made."92 These authors argued that it is unclear whether the stock market suffers from myopia, i.e., whether it undervalues long-term profit in favor of short-term profit. ${ }^{93}$ They remained unconvinced that myopia exists and raised the possibility that "allegations of myopia are a foil for managerial failure to deliver results."94 However, they acknowledge the theoretical and empirical

\footnotetext{
${ }^{92}$ Kahan \& Rock, supra note 38, at 1022, 1068, 1089. For additional analyses of shorttermism, see Lynne Dallas, Short-Termism, The Financial Crisis, and Corporate Governance, 37 J. CORP. L. 264 (2011); Emeka Duruigbo, Tackling Shareholder ShortTermism and Managerial Myopia (unpublished manuscript, Apr. 4, 2011), available at http://papers.ssrn.com/sol3/papers.cfm?abstract_id=1802840; Kent Greenfield, The Problem of Short-Termism (unpublished manuscript, Oct. 1, 2011), available at http://lawdigitalcommons.bc.edu/cgi/viewcontent.cgi?article=1378\&context=lsfp (last visited Sep. 16, 2012).

${ }^{93} \mathrm{Id}$. at $1084-85$.

${ }^{94}$ Id. at 1085 (citing Barry Rosenstein, Activism Is Good for All Shareholders, Fin. Times, Mar. 10, 2006, at 17).
} 
support in the finance literature for the existence of market myopia ${ }^{95}$ and suggest that the growth of private equity firms indicates that myopia indeed may be a "serious problem."96

Yet there is a body of management and accounting research dedicated specifically to short-termism. ${ }^{97}$ In a 1996 article, management scholar Kevin J. Laverty developed five theoretical explanations for how suboptimal short-termism might exist within a firm: flawed management practices, managerial opportunism, stock market myopia, fluid and impatient capital, and information asymmetries. ${ }^{98}$ Laverty argued that short-termism results from the problem of "intertemporal choice," when there are "decisions in which, with respect to maximizing profit or achieving some other objective, the course of action that is best in the short term is not the same course of action that is best over the long run."99 Laverty concluded that short-termism is caused by a complex interaction of individual, organizational, and economic factors, necessitating a research agenda that focuses specifically on how managers respond to the challenge of intertemporal choice. ${ }^{100}$

${ }^{95}$ Id. (citing Richard E. Kihlstrom \& Michael L. Wachter, Why Defer to Managers? A Strong-Form Efficiency Model (Univ. Pa. Law Sch. Inst. for Law \& Econ., Research Paper No. 05-19, 2005); Andrei Shleifer \& Robert W. Vishny, Equilibrium Short Horizons of Investors and Firms, 80 AM. ECON. REV. 148 (1990); Jeremy C. Stein, Efficient Capital Markets, Inefficient Firms: A Model of Myopic Corporate Behavior, 104 Q.J. ECON. 655 (1989); Jeremy C. Stein, Takeover Threats and Managerial Myopia, 96 J. POL. ECON. 61 (1988)). Nonetheless, despite citing the accounting literature demonstrating the empirical existence of myopia as we describe infra, Kahan \& Rock maintain that "the empirical evidence on the extent and magnitude of myopia is sketchy at best.” $I d$.

${ }^{96} I d$. at 1086.

${ }^{97}$ Adherents to the efficient markets hypothesis will likely object that markets "see through" accounting techniques and should internalize all available information about the effect of short-termism, such that finance is the only discipline required to determine whether a given phenomenon increases shareholder value. Yet as explained supra Section III.A.2, the efficient market hypothesis largely lacks empirical support whereas the existence of market myopia is based on theoretical and empirical research.

${ }^{98}$ Kevin J. Laverty, Economic "Short-Termism": The Debate, The Unresolved Issues, and the Implications For Management Practice And Research, 21 ACADEMY OF MGM’T REV. 825, 835 (1996).

${ }^{99} \mathrm{Id}$. at 828.

${ }^{100} I d$. at 847 . 
Management scholar Brian Bushee at the Wharton School subsequently found substantial empirical support for the link between the short-term orientation of certain institutional investors (e.g. hedge funds) and managerial short-termism within firms. In a 1998 article published in the Accounting Review, Bushee showed that "predominant ownership by 'transient' institutions - which have high portfolio turnover and use momentum trading strategies . . . significantly increases the likelihood that managers cut R\&D to manage earnings." "101 Hedge funds are the prototypical type of "transient" institutional investor, often holding shares for less than one day. ${ }^{102}$ In a subsequent piece, Bushee found further empirical support for a correlation between transient institutional blockholding and managerial myopia:

The results indicate that high levels of ownership by transient institutions are associated with overweighting of the near-term earnings component of value and underweighting of the long-term earnings component. The future-returns test finds trading strategy returns that are consistent in sign with mispricing and statistically significant two, three, and four years after the portfolio formation date. Thus, transient institutions not only exhibit strong preferences for near-term earnings, but these preferences also translate into significant misvaluations. ${ }^{103}$

Bushee's findings are consistent with other empirical studies that suggest a correlation between transient institutional ownership and a willingness to inflate short-term earnings. ${ }^{104}$

${ }^{101}$ Brian Bushee, The Influence of Institutional Investors on Myopic R\&D Investment Behavior, 73 ACCTG. REV. 305, 307 (1998).

${ }^{102}$ Kahan \& Rock, supra note 38, at 1083 ("Hedge funds come close to being the archetypal short-term investor. For some funds, holding shares for a full day represents a 'long-term' investment.”) (citing Raagas De Ramos, Concerns over Hedge Funds Rise as Market Volatility Rises Globally, WALL ST. J., June 15, 2006, at C5).

${ }^{103}$ Brian J. Bushee, Do Transient Investors Prefer Near-Term Earnings over Long-Run Value?, 18 CONTEMP. ACCTG. RESEARCH 207 (2001).

${ }^{104}$ E.g., Victor L. Bernard \& Jacob K. Thomas, Evidence That Stock Prices Do Not Fully Reflect The Implications Of Current Earnings For Future Earnings, 13 J. AcCTG. \& 
These results do not imply that markets always inefficiently ascribe more value to short-term results. The finance research cited by Bebchuk and Jackson is not necessarily erroneous. Even if hedge fund activism has historically benefitted companies on average, technological advances and innovations in synthetic ownership may have just now rendered the ten-day window an incentive for a superoptimal level of activism. Markets may have not yet internalized the detrimental effects of aggregate levels of excessive hedge fund activism. While empirical research demonstrates that short-termism may impose a cost on firms subject to hedge fund intervention, this cost need not be constant and may rise proportionately with the overall level of hedge fund activism. This could occur, for example, if managers tend to be more myopic to the extent they observe higher aggregate levels of aggregate activism.

This relationship may not be linear or even continuous: it may “jump up” at certain levels of aggregate activism if, for example, CEOs observe a "critical mass" of hedge fund activism and dramatically increase the focus on short-term earnings after this level. The historically positive correlation between hedge fund schedule 13D announcements and target firm share prices may simply indicate that the market is inefficiently misestimating the shape of this "cost curve," i.e., the distribution of the cost of short-termism resulting from this higher aggregate level of overall hedge fund intervention. ${ }^{105}$ Regulatory policy must take into consideration the potential for detrimentally excessive activism in the future, even if markets have yet to do so.

In short, despite the difficulty of reconciling short-termism with the efficient markets hypothesis, a substantial body of research suggests that hedge funds' focus on short-term earnings encourages managerial myopia. As a matter of regulatory policy, any consideration of the costs and benefits of delayed blockholder disclosure would be incomplete without weighing the potential harm caused by short-termism.

ECON. 305 (1990); Katherine Guthrie \& Jan Sokolowsky, Large Shareholders and the Pressure to Manage Earnings, 16 J. CORP. FIN. 302 (2010); see also Lynn Stout, The Mythical Benefits Of Shareholder Control, 93 VIRGINIA L. REV. 789 (2007).

${ }^{105}$ For an example of such a cost curve, see discussion infra Section IV.A. 


\section{The Social Externalities of Delayed Blockholder Disclosure}

In addition to potentially destroying long-term shareholder value by facilitating excessive hedge fund activism, delayed blockholder disclosure imposes social externalities as well. Delayed disclosure is similar to insider trading because during the ten-day window the hedge fund is trading on the material, nonpublic information regarding its accumulated holdings. Moreover, unlike with insider trading, there is no possible benefit from the dissemination of inside information regarding the company. ${ }^{106}$ As the debate over reforming the section 13(d) disclosure window concerns regulatory policy, it is essential to consider these social effects as well.

\section{Impairing Liquidity, Higher Transaction Costs and Chilling Effects}

Similar to insider trading, delayed blockholder disclosure permits trading on asymmetric information. When a hedge fund accumulates more than 5\% beneficial ownership and trades without disclosing this ownership information, it captures the entire premium that would have accrued to the share price were this information regarding its level of ownership disclosed immediately. Admittedly, trading during the ten-day window does not constitute insider trading as a matter of doctrinal law. Insider trading doctrine requires a violation of a fiduciary duty or other duty of trust and confidence under either the classical or misappropriation theory. ${ }^{107}$ There is no such fiduciary duty as a matter of doctrinal law when material nonpublic information is created by an outside investor.

\footnotetext{
${ }^{106}$ See discussion infra p. 34.

107 See, e.g., Chiarella v. United States, 445 U.S. 222, 232 (1980) (explaining that insider trading liability arises from violating a duty to disclose which is present only when there is a relationship of agency, fiduciary, or a " person in whom the sellers had placed their trust and confidence“) relationship of trust and confidence”); United States v. O’Hagan, 521 U.S. 642, 663 (1997) ("[M]isappropriation theory bars only 'trading on the basis of information that the wrongdoer converted to his own use in violation of some fiduciary, contractual, or similar obligation to the owner or rightful possessor of the information."”) (quoting Barbara Bader Aldave, Misappropriation: A General Theory of Liability for
} 
A Private ORdering Solution to BlOCKHOLDER Disclosure

$1 / 10 / 13$

However, an economic justification for the prohibition on insider trading is that trading on asymmetric information leads to increased transaction costs and reduced liquidity as market makers adjust the bid/ask spread to compensate for losses in trading with insiders holding superior information about the share price. ${ }^{108}$ In the words of one scholar:

The far more serious concern regarding the harm suffered by price-function traders due to insider trading is the likelihood that market professionals do not absorb these losses themselves, but instead pass those costs on to public investors by altering their prices to reflect the risk of insider trading borne by market professionals, leading to increased bid-ask spreads and a potentially less liquid securities market. ... . [A]t least some studies indicate that markets characterized by weaker insider trading regimes are less liquid than those markets in which prohibitions against insider trading are stringently enforced. ${ }^{109}$

Trading on Nonpublic Information, 13 HOFSTRA L.REV. 101, 119 (1984) (internal quotation marks omitted)).

${ }^{108}$ See, e.g. Hayne E. Leland, Insider Trading: Should It Be Prohibited?, 100 J. PoL. ECON. 859 (1992); Michael J. Fishman and Kathleen M. Hagerty, Insider Trading and the Efficiency of Stock Prices, 23 RAND J. ECON. 106 (1992). The literature on this socalled "adverse selection" theory is vast. See generally Stanislav Dolgopolov, Insider Trading and the Bid-Ask Spread: A Critical Evaluation of Adverse Selection in Market Making, 33 CAP. U. L. REV. 83 (2004) (critiquing the adverse selection theory in the context of insider trading but also providing a comprehensive review of the literature). ${ }^{109}$ Kimberly D. Krawiec, Fairness, Efficiency, and Insider Trading 95 Nw. U. L. REV. $443,469-70$ (2001) (citing Laura N. Beny, A Comparative Empirical Investigation of Agency and Market Theories of Insider Trading (1999) (unpublished manuscript, on file with Kimberly D. Krawiec); Utpal Bhattacharya \& Hazcm Daouk, The World Price of Insider Trading (2000) (unpublished manuscript, on file with Kimberly D. Krawiec)). This analysis is accepted even by advocates of considering legalizing insider trading. E.g., David D. Haddock \& Jonathan R. Macey, A Coasian Model of Insider Trading, 80 Nw. U. L. REV. 1449, 1457 (1986). 
Incidentally, recent theoretical and empirical research suggests that information asymmetry raises firms' cost of capital more generally, particularly in imperfect markets. ${ }^{110}$

These concerns are particularly relevant to delayed blockholder disclosure. Market participants who sell to hedge funds engaging in stealth accumulations of substantial blocks of ownership will have lost the opportunity to benefit from the disclosure premium when the beneficial ownership is disclosed upon expiration of the ten-day window. As vividly demonstrated by the examples of J.C. Penney and Fortune Bands, this post-disclosure premium can be substantial. As hedge fund activism and stealth acquisitions during the ten-day window increase, it is quite possible that market makers will price this risk of trading with hedge funds holding secret information regarding share accumulations into bid/ask spreads, impairing liquidity and raising transaction costs for market participants.

This is particularly likely in light of the difference between a schedule $13 D$ and $13 G$ filing discussed previously. ${ }^{111}$ By permitting trading on asymmetric information regarding an upcoming schedule $13 D$ filing, the ten-day window deprives counterparties of the opportunity to capture the short-term benefit of the activist's change-of-control intent. The examples of J.C. Penney and Fortune Brands demonstrate how this short-term payoff could dramatically move share prices, suggesting that the potential loss from trading with a blockholder engaging in a stealth acquisition is substantial and thus more likely to affect market liquidity.

Moreover, as with insider trading, permitting hedge funds to trade during the ten-day window without disclosing accumulated share ownership and unilaterally capture the premium that would inure upon disclosure would engender a distrust of capital markets among investors. By undermining the values of equal opportunity and transparency that encourage participation in the capital markets, trading on asymmetric

${ }^{110}$ E.g., David Easley \& Maureen O'hara, Information and the Cost of Capital, 59 J. FiN. 1553 (2004); John S. Hughes, Jing Liu \& Jun Liu, Information Asymmetry, Diversification, and Cost of Capital, 82 ACCTG. REV. 705 (2007); Maureen O'Hara, Presidential Address: Liquidity and Price Discovery, 58 J. Fin. 1335 (2003); Richard A. Lambert, Christian Leuz \& Robert E. Verrecchia, Information Asymmetry, Information Precision, and the Cost of Capital, 16 REV. FIN. 1 (2011).

${ }^{111}$ See discussion supra p. 12. 
information could have a substantial chilling effect. In the words of former SEC Chairman Arthur Levitt: “Our markets are strong because investors are confident of their basic fairness. Trading on inside information . . . damages the entire structure of our markets, because it deeply shakes this vital investor confidence. It can especially demoralize individual investors."112

Some scholars have criticized this position, arguing that if insider trading does not actually harm investors, it cannot have a psychological chilling effect. ${ }^{113}$ But this critique takes a narrow view of harm.

Economic harm is just one type of harm-loss of trust and confidence in a fair market is an independent psychological harm that could lead some investors to refuse to participate out of fear of losing to insiders for whom the game is rigged. To use one scholar's analogy of gambling: some investors may indeed choose not to play "without an appropriate adjustment of the odds," "114 but that is a loss for society as well, in the noneconomic sense of egalitarian participation in markets. ${ }^{115}$

Finally, the primary economic justification advanced by proponents of legalization of insider trading - signaling information to improve stock price accuracy_-does not justify delayed blockholder disclosure but rather weighs in favor of immediate transparency. Under this theory, insider trading is beneficial because it acts as a signaling device, improving the accuracy of stock prices without forcing firms to disclose confidential information. ${ }^{116}$ Insiders are essentially "selling” their

${ }^{112}$ Arthur Levitt, A Question of Integrity: Promoting Investor Confidence by Fighting Insider Trading, SEC Speaks Conference (Feb. 27, 1988), available at http://www.sec.gov/news/speech/speecharchive/1998/spch202.txt.

${ }^{113}$ E.g., Stephen M. Bainbridge, Incorporating State Law Fiduciary Duties Into the Federal Insider Trading Prohibition, 52 WASH. \& LEE L. REV. 1189, 1241 (1995) ("If investors are not injured by insider trading, why should insider trading affect their confidence in the securities markets?”).

${ }^{114}$ Kenneth E. Scott, Insider Trading: Rule 10b-5, Disclosure and Corporate Privacy, 9 J. LEGAL STUD. 801, 808 (1980).

${ }^{115}$ Cf. Krawiec, supra note 109, at 465 (discussing notion of "informational egalitarianism" as fairness-based justification for prohibiting insider trading).

${ }^{116}$ See STEPHEN M. BAINBRIDGE, THE LAW AND ECONOMICS OF INSIDER TRADING: A COMPREHENSIVE PRIMER 66 (2001), available at http://papers.ssrn.com/paper.taf?abstract_id=261277 (citing HENRY MANNE, INSIDER TRADING AND THE STOCK MARKET 77-91 (1966)). 
A PRIVATE ORDERING SOLUTION TO BLOCKHOLDER DisClOSURE

material nonpublic information to the market, which improves overall market efficiency by making prices more accurate. ${ }^{117}$

While this rationale has been criticized, ${ }^{118}$ it plainly militates in favor of disclosure when applied to outsiders holding material nonpublic information. There would seem to be no better way to ensure accurate stock prices than forcing immediate disclosure upon acquiring beneficial ownership in excess of the $5 \%$ threshold. This Article is not advocating a mandatory rule of universal immediate disclosure, ${ }^{119}$ but the importance of price efficiency constitutes yet another cost of delayed blockholder disclosure that must be weighed when setting regulatory policy.

\section{Depriving Counterparties of Autonomy}

The foregoing discussion took a strict consequentialist approach, i.e., measuring the costs of delayed blockholder disclosure solely by its effects on society as a whole. But there is another source of non-economic costs imposed by the ten-day window: the loss of autonomy inherent in inducing a counterparty to trade on a deceptive premise.

In an article in the Columbia Business Law Review, Ian B. Lee justifies the prohibition on insider trading on deontological grounds. ${ }^{120}$ Unlike the "emotion and empty assertion"121 that characterized the debate over insider trading prior to Henry Manne's economic argument in favor of legalization, ${ }^{122}$ Lee develops a rigorous philosophical theory of fairness in markets based on respecting the autonomy of market participants. In

${ }^{117}$ As noted $i d$., further discussion of the signaling effect may be found in William J. Carney, Signaling and Causation in Insider Trading, 36 CATH. U. L. REV. 863 (1987); Dennis S. Corgill, Insider Trading, Price Signals, and Noisy Information, 71 IND. L.J. 355 (1996); Marcel Kahan, Securities Laws and the Social Costs of "Inaccurate" Stock Prices, 41 DuKe L.J. 977 (1992)).

${ }^{118}$ E.g., Robert A. Prentice \& Dain C. Donelson, Insider Trading as a Signaling Device, 47 Am. Bus. L. J. 1 (2010); Roy A. Schotland, Unsafe at Any Price, 53 VA. L. ReV. 1425, 1443 (1967).

${ }^{119}$ For a discussion of this Article's proposed solution, see infra Part IV.

${ }^{120}$ Ian B. Lee, Fairness and Insider Trading, 2002 ColuM. Bus. L. REV. 119.

${ }^{121}$ Jonathan R. Macey, Securities Trading: A Contractual Perspective, 50 CASE W. RES.

L. REV. 269, 289 (1999).

${ }^{122}$ MANNE, supra note 78. 
his view, in a fair market, the law should seek to promote the respect of autonomy between trading counterparties. ${ }^{123}$ Under this rationale, Lee justifies the traditional legal prohibition on coercion and deception, ${ }^{124}$ e.g., contracts made under duress or fraud. With respect to trading on asymmetric information, Lee argues:

[I]nformation improves a party's options . . . in a way that goes to the quality of the decision as an exercise of autonomy: it strengthens the connection between the decision and the eventual outcomes. The closer the connection, the more the decision can be said to relate to the eventual outcome itself. Conversely, the less informed the decision, the weaker the connection between the decision and the outcomes and the more attenuated the decision-maker's autonomy. ${ }^{125}$

Withholding material information that is beneficial to counterparties undermines their autonomy by denying them the opportunity to "make their choice more autonomous and the transaction, therefore, more successful."126 Accordingly, since securities regulation should promote fair markets, it should prohibit any trading "while in possession of nonpublic information that would affect the investment decisions of other market participants."127

This analysis is not limited to doctrinal insider trading. Any trading on asymmetric information deprives counterparties of autonomy by misleading them regarding the nature of their transaction. The company no longer has beneficial ownership $x$ but rather $x+h$, with hedge fund $h$ as a substantial blockholder having a control intent (as evidenced by the future filing of schedule $13 D$ rather than $13 G$ ). Moreover, the

\footnotetext{
${ }^{123}$ Lee, supra note 120, at 146-47 ("In a fair market, each participant treats the values of neutrality and autonomy not simply as values to which he or she alone is entitled, but as values which are to be respected equally for all those with whom he or she trades.").

${ }^{124} \mathrm{Id}$. at 147.

${ }^{125} \mathrm{Id}$. at $152-53$.

${ }^{126} I d$. at 157.

${ }^{127} \mathrm{Id}$.
} 
A PRIVATE ORDERING SOLUTION TO BLOCKHOLDER DISCLOSURE

hedge fund is not merely withholding this information. It is directly thwarting its trading partner's success by depriving him or her of the voluntary choice to wait until the public announcement or demand a higher price in light of the expected premium. Trading on asymmetric information regarding beneficial ownership during the ten-day window undermines counterparties' autonomy and frustrates their ability to realize a successful transaction by deceitfully capturing the profit they would have received with disclosure.

Some might object that by participating in a market that permits trading on asymmetric information, sellers have voluntarily accepted the risk of losing this profit to blockholders engaging in a stealth accumulation. Under this view, there is no autonomy violation because sellers implicitly waived any moral right to receive all material information by voluntarily participating in a market that permits trading on asymmetric information. But this critique assumes too much: participation in a market that legally sanctions trading on asymmetric information does not imply a subjective waiver of the expectation to receive all material information. As a legal matter, contract law might impute such consent unless a seller specifically opts out in the contract of sale. But moral harm is distinct from legal liability. A fair market that upholds the autonomy of trading participants should presume that counterparties are morally entitled to make decisions with the highest possible degree of autonomy, i.e., with disclosure of all material information held by counterparties.

Analytically, this moral presumption is not waived because a market legally permits exploitation of information asymmetries. The legal status quo is merely descriptive, and does not imply anything regarding a seller's subjective volition regarding full disclosure. Consider the example of a seller who insists on full disclosure yet trades (unknowingly) during the ten-day window. In light of the seller's affirmative statement that he or she has not waived the moral expectation of receiving all material information, it would be difficult to conclude that the sale transaction invalidates this explicit expression of will. The law may not uphold the seller's autonomy-i.e., by giving the buyer the right to trade without disclosing its accumulated stake-but that does not imply that the seller has voluntarily waived his or her moral entitlement to make a fully informed decision. This analysis is not limited to express objections: in a 
fair market that upholds counterparties’ autonomy, an insistence on full disclosure of all material information should be the default rule. Unless a seller expressly waives his or her moral entitlement to a fully informed decision, trading on asymmetric information deprives such a seller of some degree of autonomy and thereby causes moral harm.

This does not imply that hedge funds or other market participants are morally obligated to disclose subjective intent, future plans, or nonmaterial information. But delayed blockholder disclosure permits a market participant to intentionally withhold objective information regarding its share accumulation, knowing that disclosure would have affected its counterparty's trading decision, and then to profit by tacitly misleading him or her. In the case of J.C. Penney and Fortune Brands, such non-disclosure led to nearly $\$ 300$ million in deceptively induced profits. ${ }^{128}$ Such exploitation of trading counterparties undermines the mutual respect for autonomy that lies at the core of a fair market.

Nonetheless, this moral harm does not mean that delayed disclosure should be absolutely prohibited. As Lee acknowledges, there may be economic justifications for permitting this moral harm in certain circumstances. ${ }^{129}$ Indeed, he arguably brushes aside bargained-for opt-out far too quickly, ${ }^{130}$ as express waiver of the right to receive all material information would fully respect the seller's autonomy. But in the absence of such express opt-out, there is moral harm from delayed disclosure that must be weighed alongside the benefits of hedge fund activism. It is not enough to consider only one half of the equation.

\section{Private Ordering, FeEs ANd Compensation}

This Part shows why a single mandatory disclosure duration is suboptimal and suggests a private ordering approach that would facilitate efficiently determining the optimal disclosure length for each firm. This Part also proposes imposing a filing fee to internalize the social cost of delayed disclosure and a compensation regime to ameliorate the injury to victims of trading on asymmetric information.

${ }^{128}$ See discussion supra Section II.A.

${ }^{129} \mathrm{Id}$. at 189.

${ }^{130}$ See id. at 187. 
A Private Ordering SOLUTION TO BlockHOLDER Disclosure

\section{A. Why a Single Mandatory Disclosure Duration Is Suboptimal}

The suboptimal nature of the current ten-day window is simple to grasp intuitively. ${ }^{131}$ Consider two firms, $\mathrm{A}$ and $\mathrm{B}$, with the following hypothetical total and marginal firm-specific costs and benefits from different levels of blockholder disclosure:

131 The Appendix contains a simple model and discussion of additional problems of statistical inference that further demonstrate the challenge with finding an optimal, onesize-fits-all mandatory disclosure duration. 


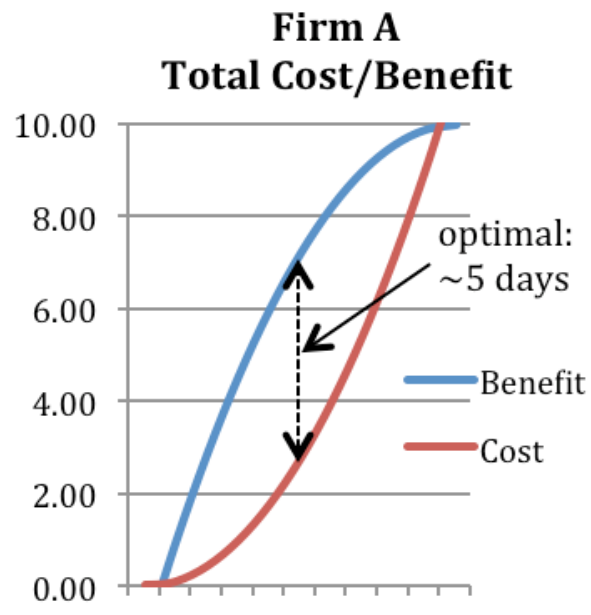

012345678910

Disclosure Duration (Days)

Firm A

Marginal Cost/Benefit

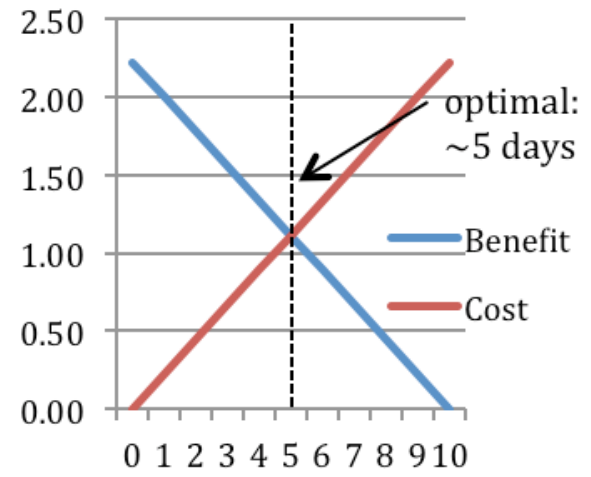

Disclosure Duration (Days)
Firm B Total Cost/Benefit

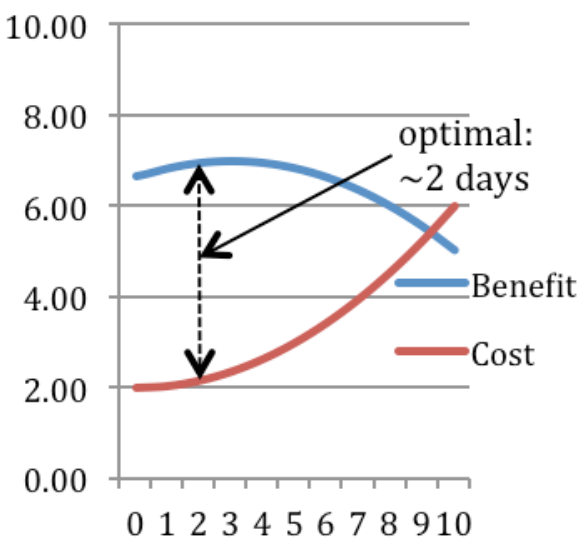

Disclosure Duration (Days)

Firm B Marginal Cost/Benefit

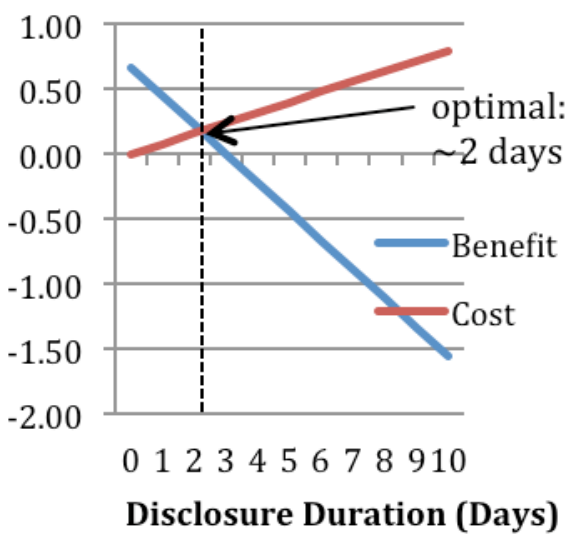

The upper curves reflect a firm's total cost and benefit from blockholder disclosure and the lower curves reflect a firm's marginal cost and benefit, i.e., the cost or benefit from one additional day of delayed disclosure. These graphs reflect the intuitive assumption that marginal costs and benefits of delayed blockholder disclosure are generally 
positive-i.e., hedge funds obtain a greater benefit for each additional day of disclosure, which imposes an increasing cost on firms as well. ${ }^{132}$ These graphs demonstrate that the optimal duration for each firm is the number of days that maximizes the difference between the total cost and benefit curves when the benefit exceeds the cost. Put differently, the optimal duration is the number of days where the marginal benefit from one additional day of disclosure equals its marginal cost.

These examples demonstrate that a universal mandatory blockholder disclosure duration is suboptimal because it is over- and under-inclusive. For example, consider a duration of 5 days. For firms like firm A, this would be nearly optimal. For firms like firm B, it would be much less optimal than a shorter duration, e.g., 2 days. More generally, for some firms, the benefit from monitoring and disciplining management at a shorter duration would exceed the costs of short-termism. For others, this duration would encourage excessive hedge fund activism, imposing costs that exceed the benefits to those firms.

The costs and benefits of hedge fund activism may vary between firms for idiosyncratic, firm-specific reasons. Certain companies may be more vulnerable to managerial slack than others. A particularly charismatic CEO recruited externally may be given greater leniency by the board of directors - and thus have greater potential for suboptimal performance - than a management team promoted from within on a provisional basis. Conversely, hedge fund activism may be more likely to induce short-termism at certain firms if management had previously had a challenging experience with dissatisfied activist shareholders.

One factor common to all firms that affects the costs and benefits of hedge fund activism is the degree of antitakeover measures that a firm had adopted. In general, the value of one form of shareholder activism depends on the ease at which other forms of activism may be alternatively employed to reduce managerial slack. Antitakeover measures such as poison pills and classified boards make it harder to reduce managerial

\footnotetext{
${ }^{132}$ The benefit curve for Firm B demonstrates another possibility, namely that the benefit starts decreasing after a certain point in time, i.e., if activism would not be more beneficial for the firm if the hedge fund had an additional day of delayed disclosure.
} 
slack through the threat of a hostile takeover. ${ }^{133}$ When strong takeover defenses are present, hedge fund activism could provide a firm with a greater benefit because it may be one of the few remaining means of disciplining management.

Conversely, when takeover defenses are weak or absent, hedge fund activism may exacerbate management's vulnerability to aggressive, activist shareholders seeking to maximize short-term profits. Accordingly, the level of antitakeover provisions may directly determine the costs and benefits of hedge fund activism for a given firm. This is why a private ordering solution for delayed blockholder disclosure would be a particularly effective approach: the shareholders of each firm are best suited to choose the duration that preserves managerial discipline while avoiding excessive short-termism in light of the firm's existing antitakeover provisions.

Interestingly, there is a current trend among public companies towards reducing takeover defenses, particularly classified boards. Efforts by the Harvard Law School's Shareholders Rights Project and the American Corporate Governance Institute led to board declassification among 21 S\&P 500 companies in 2011. ${ }^{134}$ In its 2012 proxy voting summary guidelines, the influential Institutional Shareholder Services (ISS) recommends that institutional shareholders vote against director nominees who adopt long-term poison pills or refuse to declassify boards following shareholder approval of non-binding proposals seeking such action. ${ }^{135}$ This trend towards reducing antitakeover defenses suggests that shortening the blockholder disclosure window might be particularly

\footnotetext{
${ }^{133}$ For a discussion of how takeovers reduce managerial slack, see generally Michael Jensen, Takeovers: Their Causes and Consequences, 2 J. ECON. PERSPECTIVES 21 (1988); David Scharfstein, The Disciplinary Role of Takeovers, 55 REV. ECON. STUD. 185 (1988).

${ }^{134}$ Lucian Bebchuk \& Scott Hirst, Contributing to the Declassification of 21 S\&P 500 Companies: Final Tally of the Results of the ACGI's 2011 Work, HARV. L. SCH. FORUM ON CORP. GOV. \& FIN. REG. (Oct. 23, 2012), http://blogs.law.harvard.edu/corpgov/2012/10/23/contributing-to-the-declassification-of21-sp-500-companies-final-tally-of-the-results-of-the-acgis-2011-work/\#1.

${ }^{135}$ InSTITUTIONAL SHAREHOLDER SERVICES, 2012 U.S. Proxy VOtING SUMmary GUIDELINES 11 (Dec. 19, 2011), available at http://www.issgovernance.com/files/2012USSummaryGuidelines.pdf.
} 
beneficial to target firms, increasing the likelihood that a majority of firms will prefer a default rule of immediate disclosure, as explained below. ${ }^{136}$

The following two Sections propose specific regulatory reforms to implement a private ordering solution for blockholder disclosure in light of the varying firm-specific and social costs of hedge fund activism.

\section{B. Private Ordering for Firm-Specific Delayed Disclosure}

This Section proposes a private ordering solution to setting the optimal length for the blockholder disclosure window. ${ }^{137}$ In short, the SEC should adopt a default rule of immediate disclosure or disclosure within one day of acquiring the requisite beneficial ownership, but permit individual corporations to opt-out of this rule through a shareholder amendment to the corporate bylaws. Such an amendment could authorize a longer disclosure window up to the statutory maximum of ten days. A shareholder amendment to the corporate bylaws would give shareholders the opportunity to maximize the value of their shares if a longer duration for blockholder disclosure would in fact do so.

\section{Private Ordering: Background and Proxy Access}

The notion that the securities laws should contain default rather than mandatory disclosure rules is hardly new. As early as 1978, the mandatory disclosure requirements of the Williams Act were criticized for "diluting the value of the property right in privately produced information.”138 In 1987, Jonathan R. Macey and Jeffrey M. Netter

\footnotetext{
${ }^{136}$ See discussion infra p. 48.

137 Steven Brams and I have argued elsewhere that even a private ordering approach is economically inferior to a negotiated transaction facilitated by a bargaining mechanism. Steven J. Brams \& Joshua Mitts, Law and Mechanism Design: Procedures to Induce Honest Bargaining, at *37 (working paper, 2013), available at http://papers.ssrn.com/abstract=2161045. However, such an approach is a radical departure from the status quo and would require substantial legislative reform. The private ordering solution proposed here can be implemented under the existing statute by administrative rulemaking. See discussion infra p. 46.

${ }^{138}$ Daniel R. Fischel, Efficient Capital Market Theory, the Market for Corporate Control, and the Regulation of Cash Tender Offers, 57 TEX. L. REV. 13 (1978). See also William
} 
argued that the mandatory disclosure requirements of takeover intent under regulation 13D were unnecessary and socially detrimental by deterring bidders and should be replaced by an optional amendment to a company's articles of incorporation. ${ }^{139}$

More recently, scholars have advocated competition between jurisdictions to permit firms to gravitate to more efficient securities law regimes. ${ }^{140}$ In a similar vein, Ian Ayres and Steven Choi suggest regulating so-called "outsider trading” by permitting the traded firm to elect to prohibit trading in its shares by informed outsiders such as market analysts. ${ }^{141}$ The approach taken by Ayres and Choi is similar to this Article, as they argue for a firm-specific opt-out requiring approval by "both a majority of a firm's board and a majority of a firm's shareholders."142 This Article makes a similar opt-out argument: delayed blockholder disclosure should be permitted on a firm-specific basis through a shareholder amendment to the corporate bylaws. ${ }^{143}$ Indeed, Luca Enriques, Matteo Gargantini, and Valerio Novembre advocated a similar approach in the European context, suggesting shareholder disclosure opt-out by both issuers and Member States. ${ }^{144}$

J. Carney, Toward a More Perfect Market for Corporate Control, 9 DEL. J. CORP. L. 593, 597 (1984) (criticizing mandatory disclosure of takeover intentions).

139 Jonathan R. Macey \& Jeffry M. Netter, Regulation 13D and the Regulatory Process, 65 WASH. U. L. Q. 131, 154 (1987) ("Interestingly, no one has ever explained why target firms could not themselves provide incentives for bidders to disclose the information required by the Williams Act if such disclosure would benefit shareholders. If shareholders of potential target firms find such information of value, they could make appropriate adjustments in their firms' articles of incorporation that would require the disclosure.”).

${ }^{140}$ E.g., Stephen J. Choi \& Andrew T. Guzman, Portable Reciprocity: Rethinking the International Reach of Securities Regulation, 71 S. CAL. L. REV. 903, 914 (1998); Roberta Romano, Empowering Investors: A Market Approach to Securities Regulation, 107 YALE L.J. 2359, 2402 (1998).

${ }^{141}$ Ian Ayres \& Stephen Choi, Internalizing Outsider Trading, 101 MiCH. L. REV. 313, 389 (2002).

${ }^{142} \mathrm{Id}$. at 389.

${ }^{143}$ Unlike Ayres and Choi, this Article advocates for approval of an amendment to the bylaws by shareholders alone. See discussion infra p. 50.

${ }^{144}$ Luca Enriques, Matteo Gargantini \& Valerio Novembre, Mandatory and ContractBased Shareholding Disclosure, 25 UNIF. L. REV. 713, 736 (2010). 
In the economic analysis above, adopting a private ordering approach is akin to recognizing that no external regulator can find the firm-specific optimal disclosure length better than the firm's shareholders. They have a natural incentive to maximize the benefit from delayed disclosure-i.e., encouraging hedge fund activism to monitor and discipline management-while minimizing the costs of such delayed disclosure-i.e., an excessive focus on short-termism which would depress the long-term value of their shares.

Admittedly, this approach assumes the group of shareholders required to approve the bylaws amendment are seeking to maximize longterm value. It would obviously not apply when a majority of a company's shares are held by investors who themselves have a short-term orientation. One way to prevent a simple reversal of the disclosure duration window is to require a supermajority for future amendments. ${ }^{145}$ Yet in the vast majority of cases, empowering shareholders to opt-out of immediate disclosure would encourage determination of the efficient firm-specific blockholder disclosure window duration.

Interestingly, a private ordering approach to proxy access was widely advocated in the debate over the SEC's now-defunct Rule 14a-11. As proposed, Rule 14a-11 would have required the inclusion of shareholders' director nominations in a reporting company's proxy materials. ${ }^{146}$ Leading corporate law firms and industry groups, including Wachtell, Lipton, Rosen \& Katz, Cravath, Swaine \& Moore LLP and the Business Roundtable, advocated permitting firms to opt-out of these requirements through an amendment to the corporate bylaws. ${ }^{147}$ This

\footnotetext{
${ }^{145}$ See discussion infra p. 52.

${ }^{146}$ Facilitating Shareholder Director Nominations, Exchange Act Release No. 34-60089, 74 Fed. Reg. 29024 (proposed June 18, 2009).

${ }^{147}$ E.g., Letter from Wachtell, Lipton, Rosen \& Katz to Elizabeth Murphy, Sec'y, U.S. Sec. \& Exch. Comm'n 10 (Aug. 17, 2009), available at http://www.sec.gov/comments/s7-10-09/s71009-263.pdf; Letter from Alexander M. Cutler, Chairman \& Chief Executive Officer, Eaton Corp., and Chair, Corp. Leadership Initiative, Bus. Roundtable, to Elizabeth Murphy, Sec'y, U.S. Sec. \& Exch. Comm’n 47 (Aug. 17, 2009), available at http://www.sec.gov/comments/s7-10-09/s71009-267.pdf; Letter from Cravath, Swaine \& Moore LLP et al. to Elizabeth Murphy, Sec'y, U.S. Sec. \& Exch. Comm'n 1-2 (Aug. 17, 2009), available at http://www.sec.gov/comments/s7-1009/s71009- 212.pdf.
} 
position was echoed by academic scholars, including Lucian Bebchuk and Scott Hirst, ${ }^{148}$ who advocated an opt-out regime with a default rule permitting proxy access. ${ }^{149} \mathrm{~A}$ broader argument was advanced by $\mathrm{D}$. Gordon Smith, Matthew Wright and Marcus Kai Hintze, who advocated private ordering through shareholder amendments to corporate bylaws more generally. ${ }^{150}$

In Business Roundtable v. SEC, the D.C. Circuit struck down Rule 14a-11, the final version of which did not contain a private ordering exception. ${ }^{151}$ But the changes to Rule 14a-8 remained untouched by this decision, which give shareholders the ability to propose bylaws addressing election-related matters. ${ }^{152}$ In essence, the current regime is a de facto private ordering system where shareholders may effect changes to election procedures by proposing amendments to the bylaws in a company's proxy statement. ${ }^{153}$ Accordingly, this Article's private ordering proposal is not without precedent, nor is it far removed from positions previously advocated by practitioners and the academic community.

${ }^{148}$ Lucian A. Bebchuk and Scott Hirst, Private Ordering and the Proxy Access Debate, 65 Bus. LAW. 329, 351-52 (2010); see also Brett H. McDonnell, Setting Optimal Rules for Shareholder Proxy Access, 43 ARIZ. ST. L.J. 67 (2011) (making a similar argument to that of Bebchuk and Hirst).

${ }^{149} \mathrm{Id}$.

${ }^{150}$ D. Gordon Smith, Matthew Wright \& Marcus Kai Hintze, Private Ordering with Shareholder Bylaws, 80 FordHAM L. REV. 125, 170 (2011). But see Brett H. McDonnell, "Private Ordering” Taken a Tad Too Far, 6 FordHAM L. REV. Res GeSTAE 32 (2011) (generally supporting but criticizing portions of Smith, Wright \& Hintze’s proposals). ${ }^{151} 647$ F.3d 1144 (D.C. Cir. 2011).

${ }^{152}$ See also McDonnell, supra note 108, at 36 ("For decades, the misbegotten 'relates to an election' exclusion prevented shareholders from using Rule 14a-8 to propose bylaws setting the rules for shareholder elections. The SEC's recent proxy access rules wisely eliminated this exclusion (more or less), and the D.C. Circuit's recent decision in Business Roundtable v. SEC does not change that.").

${ }^{153}$ See id. at 36 ("Given the stringency of [the new Rule 14a-11], what really mattered was amending Rule 14a-8 to allow shareholders to create their own more generous rules, and as mentioned, that change remains in place.”). But see Smith, Wright \& Hintze, supra note 150, at 185 (discussing other limitations on proxy proposals in Rule 14a-8 and advocating their elimination). 
A PRIVATE ORDERING SOLUTION TO BLOCKHOLDER DisClOSURE

\section{Implementing Private Ordering for Blockholder Disclosure}

A private ordering solution to blockholder disclosure consists of (1) replacing the current mandatory rule of a ten-day window with a default rule of immediate disclosure and (2) instituting an opt-out procedure. These two reforms could be implemented by a legislative rule within the SEC's existing authority under the Dodd-Frank Act. Section 929R does not proscribe any limitation on the SEC's rulemaking authority other than a ten-day maximum but simply refers to "such shorter time as the Commission may establish by rule."

Under the doctrine articulated in Chevron, U.S.A., Inc. v. Natural Resources Defense Council, Inc., administrative agencies are shown considerable deference when interpreting an enabling statute. ${ }^{155}$ Construing section 929R as permitting a firm-specific blockholder disclosure duration would likely pass the first step of the Chevron analysis for the validity of an agency interpretation of a statute because such an interpretation is "unambiguously" implied by the statutory text. ${ }^{156}$ The text of section 929R simply refers to "such shorter time as the Commission may establish by rule." A straightforward reading of this text does not imply that the "time" must be universal and equal for all firms. Accordingly, it is likely that an SEC interpretation of section 929R as permitting a private ordering system would pass the first step of Chevron.

Moreover, even if a court were to hold that this interpretation is not "unambiguously" implied by the statute, a private ordering interpretation would almost certainly be upheld as a "permissible construction of the statute."157 It is clearly not "arbitrary, capricious, or manifestly contrary to the statute." 158 There is no implication whatsoever in the text of section

\footnotetext{
${ }^{154}$ Dodd-Frank Wall Street Reform and Consumer Protection Act, Public Law 111-203, 124 Stat. 1866, § 929R (Jul. 21, 2010).

${ }^{155} 467$ U.S. 837, 842 (1984).

${ }^{156} \mathrm{Id}$. at 843.

${ }^{157} \mathrm{Id}$.

${ }^{158} I d$. at 844.
} 
929R that the disclosure duration must be universal. Accordingly, the SEC's interpretation would be "given controlling weight."159

The default disclosure duration should be set as short as possible, e.g., immediately, in order to compel shareholders to opt-out if they wish to encourage hedge fund activism. ${ }^{160}$ The SEC should give effect to congressional intent when interpreting the statute, ${ }^{161}$ and comments by the House Committee on Financial Services indicate that the purpose of section 929R is to reduce mispricing. ${ }^{162}$ If the SEC were to retain the existing ten-day rule as a default rule, firms would be forced to opt-out to impose a shorter duration on blockholders. As opt-out requires reaching shareholder consensus-indeed, a supermajority under this Article's proposal-such an approach would leave more firms with the default tenday rule. This would be less effective at reducing mispricing and improving the information available in the market than a default rule of immediate disclosure.

A default rule of immediate disclosure is justified under defaultrule theory as well. Much literature has discussed how the relationship between shareholders and the corporation can be analyzed as contractual. ${ }^{163}$ In a well-known article, Ian Ayres and Robert Gertner analyze "untailored defaults," where default rules are set according to

\footnotetext{
${ }^{159} I d$.

${ }^{160}$ If immediate disclosure is impractical, one day might be used. The feasibility of immediate disclosure depends on whether the SEC and stock exchanges have the technical means to detect intraday accumulation beyond the 5\% threshold and can facilitate intraday reporting.

${ }^{161}$ See generally CHARLES H. KoCH, JR., 4 ADMIN. L. \& PRAC. § 11:33 (3d ed. ) ("Courts ... may be skeptical of an agency's reliance on legislative history as justification for an agency's statutory interpretation. ... . [But g]enerally committee reports, particular reports from the conference committee, can be helpful indicators of congressional intent.”); Jerry L Mashaw, Between Facts and Norms: Agency Statutory Interpretation as an Autonomous Enterprise, 55 U. TORONTO L.J. 497, 509 (2005) ("In some instances only the skillful deployment of legislative history will permit agencies to fulfill their constitutional role as faithful agents in the statute's implementation.”).

${ }^{162}$ H. Rep. No. 111-687, at 76 (2010).

163 See, e.g., Henry N. Butler, The Contractual Theory of the Corporation, 11 GEO. MASON U. L. REV. 99 (1989) (collecting sources).
} 
"what the majority of contracting parties would want."164 These are efficient when the gains to the parties for whom the default rule fulfills what they would have wanted exceed the loss to the parties who incur the cost of contracting around the default. ${ }^{165}$

In the context of a private ordering approach to blockholder disclosure, it is plausible that immediate disclosure would reflect what a majority of firms would prefer and the cost of contracting around this default imposes losses less than the gains for firms that prefer a longer duration. This is particularly likely in light of the current trend toward declassifying boards and reducing antitakeover protections, which increases the likelihood of inducing short-termism among target firms. ${ }^{166}$

Admittedly, this is only an intuition. The SEC should conduct a robust empirical study to determine how many firms would prefer a default rule of immediate disclosure vs. ten days and the cost of opting-out of this default for those firms that prefer to do so. This study may even provide empirical support for setting the default duration at some other length, e.g., five days, if that would produce gains that exceeds losses under the Ayres and Gertner framework. Nonetheless, it is likely that a majority of firms will prefer immediate disclosure, and the legislative history in favor of reducing mispricing suggests that a default rule of immediate disclosure is the right starting point for regulatory reform.

It is essential to consider the precise mechanism for shareholders to opt-out of the default rule of immediate disclosure. ${ }^{167}$ For the SEC to implement a private ordering system by administrative rule, this mechanism should not require legislative reform. There are three primary possibilities to effectuate an opt-out under Delaware corporate law: an amendment to the certificate of incorporation, a board of directors'

${ }^{164}$ Ian Ayres \& Robert Gertner, Filling Gaps in Incomplete Contracts: An Economic Theory of Default Rules, 99 YALE L.J. 90, 91 (1989) (citing Charles J. Goetz \& Robert E. Scott, The Mitigation Principle: Toward a General Theory of Contractual Obligation, 69 VA. L. REV. 967, 971 (1983)).

${ }^{165}$ See id. at 113-15. For these parties, an untailored default is a "penalty default" in Ayres and Gertner's terminology.

${ }^{166}$ See discussion supra p. 41.

${ }^{167}$ For a comprehensive discussion of altering rules-i.e., the procedural rules of optout-see generally Ian Ayres, Regulating Opt-Out: An Economic Theory of Altering Rules, 121 YALE L.J. 2032 (2012). 
amendment to the bylaws, and a shareholder amendment to the bylaws. ${ }^{168}$ For the following reasons, a shareholder amendment is the best approach to effectuate a private ordering solution.

An amendment to a Delaware corporation's certificate of incorporation requires approval by the board of directors and a majority of shareholders entitled to vote. ${ }^{169}$ Alternatively, a Delaware corporation may grant its board of directors the authority to amend the bylaws. ${ }^{170}$ However, section 109 of the Delaware General Corporate Law (DGCL) provides that shareholders always retain statutory authority to amend the bylaws directly:

After a corporation ... has received any payment for any of its stock, the power to adopt, amend or repeal bylaws shall be in the stockholders entitled to vote. . . . The fact that such power has been so conferred upon the directors or governing body, as the case may be, shall not divest the stockholders or members of the power, nor limit their power to adopt, amend or repeal bylaws. ${ }^{171}$

The fundamental reason for preferring a shareholder amendment to the bylaws as opposed to an amendment by the board of directors or even an amendment to the certificate of incorporation is that requiring approval by the board of directors would undermine the effectiveness of a private ordering solution to delayed blockholder disclosure. By definition, the interests of shareholder activists are diametrically opposed to some subset of existing management. Otherwise, these activists would take a cooperative approach to effectuating corporate change. In many cases, a solid majority of the board of directors may oppose a particular shareholder activist's agenda.

\footnotetext{
168 This analysis considers Delaware corporate law, as the vast majority of publicly traded firms are incorporated there. Yet the principles would apply elsewhere if the appropriate technical adjustments are made.

${ }^{169}$ DEL. CODE ANN. tit. 8, § 242(b)(1) (2010).

${ }^{170} I d$. at $\S 109$ (a) ("[A]ny corporation may, in its certificate of incorporation, confer the power to adopt, amend or repeal bylaws upon the directors . ...”).

${ }^{171} I d$.
} 
These directors may genuinely have shareholders' best interests in mind, although it is possible that directors may oppose hedge fund activism simply to avoid being replaced. ${ }^{172}$ Yet the noncooperative nature of the interaction between activist investors and existing management suggests that it is difficult to envision a board of directors voting to extend the duration of the blockholder disclosure window, even if it were in shareholders' best interest. More fundamentally, the rationale for a private ordering system that encourages some level of hedge fund activism is that such intervention ameliorates agency costs between shareholders and management. This implies that the decision to permit delayed blockholder disclosure should rest with shareholders alone.

The mechanics of implementing private ordering through a shareholder amendment to the bylaws are straightforward. ${ }^{173}$ Under section 109 of the DGCL, a majority of shareholders may approve an amendment to the bylaws without the board's consent. ${ }^{174}$ Technically, this could be accomplished by a shareholder submitting a blockholder disclosure opt-out proposal in the company's proxy statement for the annual meeting of shareholders under Exchange Act Rule 14a-8. ${ }^{175}$ The amendment would simply state that the firm has elected to extend the duration for reporting the acquisition of $5 \%$ or more of the beneficial ownership of its shares by a certain number of days, up to the statutory maximum of ten days. ${ }^{176}$

\footnotetext{
${ }^{172}$ Hedge fund activist Bill Ackman, for example, frequently agitates for a change in the composition of a target firm's board of directors. See, e.g., Ben Dummet, Bill Ackman Riles Canadians, WALl ST. J. (Apr. 19, 2012), http://online.wsj.com/article/SB10001424052702304299304577347831092522236.html (describing Ackman's efforts to replace half the board of Canadian Pacific Railway); Rachel Dodes, Penney to Give Activists a Say on Board, WALl ST. J. (Jan. 25, 2011), http://online.wsj.com/article/SB10001424052748703555804576101630964337152.html.

${ }^{173}$ For a comprehensive discussion of private ordering through shareholder bylaws under current Delaware law and proposals for reform, see generally Smith, Wright \& Hintze, supra note 150.

${ }_{175}^{174}$ See Del. Code AnN. tit. 8, § 109(a).

17517 C.F.R. pt. 240.14a-8. This rule consists of a series of questions and answers regarding the requirements for submitting a shareholder proposal that a company must include on its proxy statement.

${ }^{176}$ There is no economic justification for capping the duration of a private ordering blockholder disclosure window. However, the current statutory framework limits the
} 
A shareholder amendment to the bylaws to facilitate private ordering for delayed blockholder disclosure would pass the test recently articulated by the Delaware Supreme Court in CA, Inc. v. AFSCME Employees Pension Plan: "a proper function of bylaws is not to mandate how the board should decide specific substantive business decisions, but rather, to define the process and procedures by which those decisions are made." 177 The duration of the blockholder disclosure window does not relate to the substantive business decisions that are reserved exclusively to the board of directors. ${ }^{178}$ It is rather a matter of process and procedure, specifically the point in time when a blockholder must disclose his or her share accumulation under the securities laws.

As noted previously, shareholders may wish to enshrine the blockholder disclosure opt-out with a supermajority vote requirement for any further amendment. Such a requirement would prevent subsequent modification by activist shareholders who may be able to obtain sufficient support to reach a simple majority and thereby lengthen the disclosure window for future prospective blockholders. Section 216 of the DGCL provides that the "bylaws of any corporation authorized to issue stock may specify the number of shares and/or the amount of other securities having voting power ... and the votes that shall be necessary for, the transaction of any business.”179 Accordingly, current shareholders may impose a

duration that the SEC could authorize to ten days. Section 929R of the Dodd-Frank Act only permits the SEC to shorten, not lengthen, the disclosure period. 15 U.S.C.A. § $78 \mathrm{~m}(\mathrm{~d})(1)$. If Congress were to consider a statutory reform to section 13(d), it should remove this cap because the benefits of blockholder disclosure may justify a longer period for certain firms. But if that is infeasible, a private ordering solution capped at ten days could be implemented within the language of the statute.

177953 A.2d 227, 234-35. (Del. 2008).

${ }^{178}$ See DEL. CoDE ANN. tit. 8, § 141(a) ("The business and affairs of every corporation organized under this chapter shall be managed by or under the direction of a board of directors, except as may be otherwise provided in this chapter or in its certificate of incorporation.”).

${ }^{179}$ Id. at § 216(a). Section 216(a) also provides explicitly for the bylaws to impose a higher shareholder vote threshold on non-director election matters: "In the absence of such specification in the certificate of incorporation or bylaws of the corporation ... In all matters other than the election of directors, the affirmative vote of the majority of shares present in person or represented by proxy at the meeting and entitled to vote on the subject matter shall be the act of the stockholders ....”). 
supermajority requirement on future amendments simply by including such a provision in the proposal for a delayed blockholder disclosure amendment to the bylaws.

Finally, a shareholder amendment proposed through a public company's proxy statement would be a matter of public record. ${ }^{180}$ Moreover, a public company must file a form 8-K upon an amendment to its bylaws. ${ }^{181}$ Accordingly, prospective blockholders could easily discover the delayed disclosure duration adopted by a shareholder amendment to a firm's bylaws by examining a firm's proxy statement and 8-K filings.

\section{Internalizing the Social Cost of Delayed Blockholder Disclosure: A Filing Fee and Compensation Proposal}

\section{A Sliding-Scale Filing Fee for Delayed Disclosure}

To internalize the social cost of delayed blockholder disclosure, this Section proposes imposing a fee on the acquisition of shares during the delayed blockholder disclosure window. ${ }^{182}$ In other words, a hedge fund that acquires greater than $5 \%$ ownership-i.e., by purchasing shares of firms that have opted out of the default rule of immediate disclosure, when such purchases occur during the period of time authorized by the shareholder amendment to the bylaws - would be required to pay a filing fee based on the social cost resulting from the acquisition of these shares.

The computation of the delayed disclosure fee will be considered shortly, but its mechanics are straightforward. The hedge fund would pay the fee to the SEC when filing the schedule 13D, which already contains several elements necessary to compute the fee: the number of shares

${ }^{180}$ See 17 C.F.R. 240a-3(a)(1) ("No solicitation subject to this regulation shall be made unless each person solicited is concurrently furnished or has previously been furnished with ... A publicly-filed preliminary or definitive proxy statement, in the form and manner described in $\S 240.14 a-16$, containing the information specified in Schedule 14A ....”) (emphasis added).

${ }^{181}$ See 17 C.F.R. § 240.13a-11, 249.308.

${ }^{182}$ From an economic standpoint, such a filing fee would function as a "Pigovian tax." Pigou suggested forcing firms to pay for the social cost of harmful externalities as a means to reduce output to the desired level. See, e.g., ARTHUR PigOU, ThE ECONOMICS OF WELFARE (1932). 
acquired and outstanding, percent of beneficial ownership acquired, and the date at which the hedge fund crossed the 5\% threshold. ${ }^{183}$ The hedge fund would only be obligated to pay the fee for acquiring ownership exceeding the $5 \%$ threshold. The hedge fund would compute its total purchase price between the date of filing and the date of reaching the $5 \%$ level, utilizing the existing trading data currently reported in item 5(c) of schedule 13D. ${ }^{184}$ The hedge fund could calculate the fee rate using a published table similar to Table 1 below based on the total purchase price, ownership acquired during the delayed disclosure window, and the number of days between crossing the 5\% threshold and filing the 13D.

This approach envisions the delayed disclosure fee as a mandatory payment for submitting a schedule 13D later than the date of acquiring $5 \%$ beneficial ownership. While it would be a violation of the securities laws to submit a schedule 13D after the period authorized by the shareholder amendment to the firm's bylaws, the hedge fund would not be obligated to wait until the conclusion of the authorized period. This is precisely why ascertaining the social cost of delayed disclosure is such an important responsibility for a regulator looking out for the public good: regardless of the specific durations that individual firms authorize, the delayed disclosure fee will compel hedge funds to internalize the social cost of trading on asymmetric information.

Similar to the private ordering system, the SEC likely could enact the delayed disclosure fee by administrative rule without statutory reform. The SEC's authority to shorten the disclosure window is delineated by language referring solely to the duration of the window: "within such

${ }^{183}$ See 17 C.F.R. § 240.13d-101 (listing the required elements of a schedule 13D filing, including "Date of Event Which Requires Filing of This Statement," "Number of shares beneficially owned by each reporting person," and "Percent of class represented by amount in Row 11"). The relevancy of this data is explained infra in the discussion of computation of the filing fee.

${ }^{184}$ See id. ("The description of a transaction required by Item 5(c) shall include, but not necessarily be limited to: (1) The identity of the person covered by Item 5(c) who effected the transaction; (2) the date of transaction; (3) the amount of securities involved; (4) the price per share or unit; and (5) where and how the transaction was effected.”). Hedge funds could simply tabulate the average purchase price based on the transactions to be reported under item 5(c) that occurred during the delayed disclosure window. 
shorter time as the Commission may establish by rule.”185 However, unlike an agency interpretation that the duration may be set on a firmspecific basis, the imposition of a mandatory payment in exchange for a longer duration does not relate strictly to "establish[ing]" a "shorter time." Accordingly, a rule imposing a delayed disclosure fee could not be upheld under the first step of the Chevron test for the validity of an agency interpretation of a statute because Congress has not "directly spoken to the precise question at issue." ${ }^{186}$ Authority to impose a delayed disclosure fee is not "unambiguously" implied by the statutory text. ${ }^{187}$

However, a delayed disclosure fee would likely be upheld under the second step of the Chevron test as a "permissible construction of the statute.”188 Because a rule enacting a delayed disclosure fee would be promulgated under an express delegation of authority by Congress, such a regulation would be "given controlling weight unless they are arbitrary, capricious, or manifestly contrary to the statute." 189 A rule providing for a delayed disclosure fee would not likely be arbitrary or capricious, which requires showing that the SEC

has relied on factors which Congress had not intended it to consider, entirely failed to consider an important aspect of the problem, offered an explanation for its decision that runs counter to the evidence before the agency, or is so implausible that it could not be ascribed to a difference in view or the product of agency expertise. ${ }^{190}$

18515 U.S.C.A $\S 78 \mathrm{~m}(\mathrm{~d})(1)$ (emphasis added).

${ }^{186}$ Chevron, U.S.A., Inc. v. Natural Resources Defense Council, Inc., 467 U.S. 837, 842 (1984).

${ }^{187}$ Id. at 843.

${ }^{188} \mathrm{Id}$.

${ }^{189}$ Id. at 844; see, e.g., NTN Bearing Corp. of America v. United States, 368 F.3d 1369, 1375-76 (Fed. Cir. 2004) (applying second prong of Chevron test and affirming the Department of Commerce's construction of a statute because it is "neither arbitrary, capricious, nor manifestly contrary to the statute").

${ }^{190}$ National Ass'n of Home Builders v. Defenders of Wildlife, 551 U.S. 644, 658 (2007) (quoting Motor Vehicle Mfrs. Ass'n of U.S., Inc. v. State Farm Mut. Auto. Ins. Co., 463 U.S. 29, 43 (1983)). 
As long as the SEC weighs all of the available alternatives, it would pass arbitrariness review. A delayed disclosure fee would be rational to institute based on the considerations outlined in this Article.

In addition, a delayed disclosure fee would not be considered "manifestly contrary to the statute." The language of section 929R of the Dodd-Frank Act does not limit the means by which the SEC may shorten the disclosure period. Indeed, enacting a financial hurdle to delayed disclosure is one method by which the SEC can bring about a "shorter time” for disclosure. Moreover, the House Committee on Financial Services report on section 929R-plainly appropriate to consult in Chevron step two ${ }^{191}$ _supports the conclusion that the SEC's authority is not limited solely to shortening reporting timeframes:

This section provides the SEC with the authority to adopt rules to shorten reporting timeframes and help the markets receive more timely information concerning substantial ownership interests in issuers. This change is important for purposes of obtaining more accurate pricing of listed securities. $^{192}$

The italicized text indicates a broader congressional intent than simply shortening the disclosure period. A delayed disclosure fee would further the purpose of obtaining "more accurate pricing of listed securities" by penalizing delays that cause prices to diverge from what they would be if the hedge fund's accumulated ownership were known to the market.

From an economic standpoint, a delayed disclosure fee would function as a "nonlinear corrective tax" where the rate is set equal to harm, which Louis Kaplow and Steven Shavell have shown is a more efficient means of addressing externalities than linear taxes or quantity regulation. ${ }^{193}$ A nonlinear delayed disclosure fee would operate on both the price and quantity terms by increasing the rate with the proportion of

\footnotetext{
191 See Chevron, 467 U.S. at 863-66; Babbitt v. Sweet Home Chapter of Cmtys. for a Great Or., 515 U.S. 687, 704-07 (1995).

${ }^{192}$ H. Rep. No. 111-687, at 76 (2010) (emphasis added).

${ }^{193}$ Louis Kaplow \& Steven Shavell, On the Superiority of Corrective Taxes to Quantity Regulation, 4 AM. L. \& ECON. REV. 1, 4-5 (2002).
} 
accumulated ownership. ${ }^{194}$ The precise rates would be set according to the proportional social harm caused by a given hedge fund trading on asymmetric information during the delayed disclosure window.

To demonstrate how the delayed disclosure fee might be computed, consider the following hypothetical example. Assume that the net social cost of delayed disclosure is a function of the number of days of delayed disclosure and the percentage of ownership acquired during the delayed disclosure period, as demonstrated by the following graph: ${ }^{195}$

\section{Figure 3: Social Cost of Delayed Disclosure Acquisition}

\footnotetext{
${ }^{194}$ For a discussion of internalizing social externalities utilizing price and quantity regulation, see generally Ian Ayres, Narrow Tailoring, 43 UCLA L. REV. 1781 (1996).

${ }^{195}$ As this Subsection focuses on setting an optimal fee on delayed disclosure, it omits a discussion of the gross social costs and benefits of delayed disclosure. There is likely a social benefit to delayed disclosure from the increased monitoring and reduced managerial slack that hedge fund activists bring about. Such a benefit would not result from increased shareholder value (e.g., in the form of more valuable investments held by the public), however, as this Article classifies this benefit as belonging to the firm. Nonetheless, there is likely some additional, residual benefit to society from greater corporate efficiency - one example might be lower unemployment than what would have otherwise resulted from firms' failure brought about by excessive inefficiency. However, as these benefits are particularly difficult to identify and likely small compared to the cost of trading on asymmetric information, it is reasonable to focus on the social cost of delayed disclosure, which this Article terms the "net" social cost.
} 


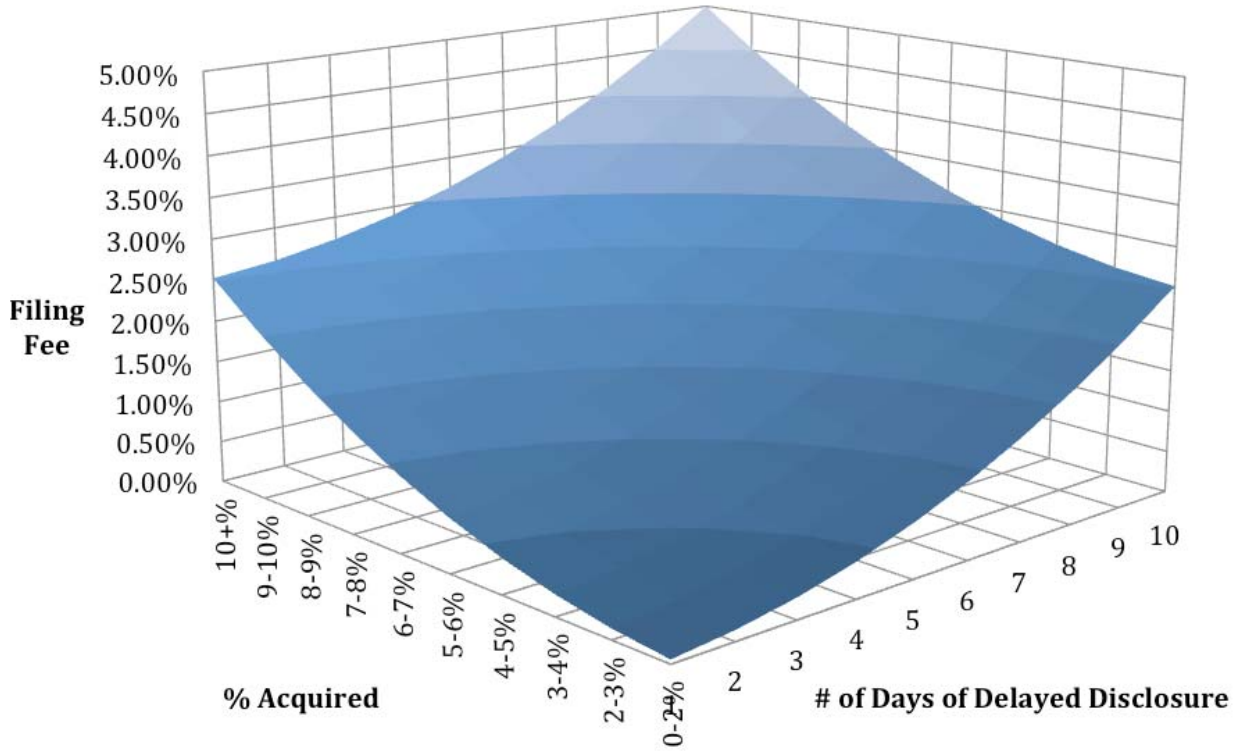

The y-axis of this graph approximates the social harm from trading in a given firm as a percent of the total purchase price paid by the hedge fund to acquire a given percent of ownership over a given number of days of delayed disclosure. A delayed disclosure fee would simply be set equal to these percentages, as given by the following example table of rates: ${ }^{.96}$

\section{Table 1: Heuristic Example of Delayed Disclosure Fee Rates}

\begin{tabular}{|c|c|c|c|c|c|c|c|c|c|c|}
\hline $\begin{array}{c}\text { \# of } \\
\text { Days }\end{array}$ & \multicolumn{8}{|c|}{ \% of Ownership Acquired During Delayed Disclosure Period } \\
\hline & $\underline{0-2 \%}$ & $\underline{2-3 \%}$ & $\underline{3-4 \%}$ & $\underline{4-5 \%}$ & $\underline{5-6 \%}$ & $\underline{6-7 \%}$ & $\underline{7-8 \%}$ & $\underline{8-9 \%}$ & $\underline{9-10 \%}$ & $\underline{10+\%}$ \\
\hline$\underline{1}$ & $0.05 \%$ & $0.13 \%$ & $0.25 \%$ & $0.43 \%$ & $0.65 \%$ & $0.93 \%$ & $1.25 \%$ & $1.63 \%$ & $2.05 \%$ & $2.53 \%$ \\
\hline$\underline{2}$ & $0.13 \%$ & $0.20 \%$ & $0.33 \%$ & $0.50 \%$ & $0.73 \%$ & $1.00 \%$ & $1.33 \%$ & $1.70 \%$ & $2.13 \%$ & $2.60 \%$ \\
\hline$\underline{3}$ & $0.25 \%$ & $0.33 \%$ & $0.45 \%$ & $0.63 \%$ & $0.85 \%$ & $1.13 \%$ & $1.45 \%$ & $1.83 \%$ & $2.25 \%$ & $2.73 \%$ \\
\hline$\underline{4}$ & $0.43 \%$ & $0.50 \%$ & $0.63 \%$ & $0.80 \%$ & $1.03 \%$ & $1.30 \%$ & $1.63 \%$ & $2.00 \%$ & $2.43 \%$ & $2.90 \%$ \\
\hline
\end{tabular}

${ }^{196}$ Both the graph and the table utilize a simple formula for calculating this example. The fee rate is equal to the number of days squared, multiplied by $0.10 / 100$. The latter term scales the rate to a maximum of $10 \%$ for ten days. 
A PRIVATE ORDERING SOLUTION TO BLOCKHOLDER DISCLOSURE

$1 / 10 / 13$

\begin{tabular}{|c|c|c|c|c|c|c|c|c|c|c|}
\hline$\underline{5}$ & $0.65 \%$ & $0.73 \%$ & $0.85 \%$ & $1.03 \%$ & $1.25 \%$ & $1.53 \%$ & $1.85 \%$ & $2.23 \%$ & $2.65 \%$ & $3.13 \%$ \\
\hline$\underline{6}$ & $0.93 \%$ & $1.00 \%$ & $1.13 \%$ & $1.30 \%$ & $1.53 \%$ & $1.80 \%$ & $2.13 \%$ & $2.50 \%$ & $2.93 \%$ & $3.40 \%$ \\
\hline$\underline{7}$ & $1.25 \%$ & $1.33 \%$ & $1.45 \%$ & $1.63 \%$ & $1.85 \%$ & $2.13 \%$ & $2.45 \%$ & $2.83 \%$ & $3.25 \%$ & $3.73 \%$ \\
\hline$\underline{8}$ & $1.63 \%$ & $1.70 \%$ & $1.83 \%$ & $2.00 \%$ & $2.23 \%$ & $2.50 \%$ & $2.83 \%$ & $3.20 \%$ & $3.63 \%$ & $4.10 \%$ \\
\hline$\underline{9}$ & $2.05 \%$ & $2.13 \%$ & $2.25 \%$ & $2.43 \%$ & $2.65 \%$ & $2.93 \%$ & $3.25 \%$ & $3.63 \%$ & $4.05 \%$ & $4.53 \%$ \\
\hline$\underline{10}$ & $2.53 \%$ & $2.60 \%$ & $2.73 \%$ & $2.90 \%$ & $3.13 \%$ & $3.40 \%$ & $3.73 \%$ & $4.10 \%$ & $4.53 \%$ & $5.00 \%$ \\
\hline
\end{tabular}

For example, a hedge fund that obtains a total of 1,000,000 shares during the delayed disclosure period of a firm with 20,000,000 shares outstanding over five days of delayed disclosure would be required to pay a filing fee equal to $1.25 \%$ of the total purchase price. ${ }^{197}$ At an average purchase price of $\$ 10$ per share, the filing fee would be approximately $\$ 125,000 .{ }^{198}$

This is just a heuristic example of a hypothetical social cost of delayed disclosure. ${ }^{199}$ But it demonstrates how a nonlinear corrective fee might be imposed according to the social harm brought about by delayed blockholder disclosure. In this example, the social cost and fee rate are a quadratic function of the number of days and the percentage of ownership acquired, scaled to a maximum rate of $5 \% .{ }^{200}$

${ }^{197} 1,000,000$ shares out of $20,000,000$ shares outstanding $=5 \%$ of the outstanding shares . According to Table 1, if $5 \%$ of the outstanding shares are acquired over 5 days of delayed disclosure, the fee would be to $1.25 \%$ of the purchase price.

${ }^{198}$ The calculation is as follows: $1,000,000$ shares acquired $\mathrm{x} \$ 10 /$ share $\mathrm{x} 1.25 \%$ fee = $\$ 125,000$.

${ }^{199}$ A method of approximating the actual social cost will be considered shortly.

${ }^{200}$ A maximum rate of $5 \%$ was chosen as the median abnormal return to hedge fund activism within a $(-20,20)$ event day window found by Brav et al. was $5.6 \%$. Brav et al., supra note 74, at 1756 . This is not an argument for setting the fee equal to hedge funds' median returns, but simply serves as a useful initial heuristic approximation of the maximum social cost that delayed disclosure might bring about. The maximum fee rate is not set to $100 \%$ because the purpose of the filing fee is not to fully compensate victims of asymmetric trading but rather to induce a socially optimal level of hedge fund activism. Imposing a fee equal to $100 \%$ of a hedge fund's acquisition during the delayed disclosure window would render such purchases cost-prohibitive unless the hedge fund expected to obtain at least a $100 \%$ profit on the acquisition of these shares plus the initial $5 \%$ block acquired at a discount. This is a high hurdle to cross. The funds from a lower delayed disclosure fee would partially compensate victims under the compensation scheme described in the next Subsection, but the primary goal of the filing fee is to induce the socially optimal level of activism. 
Applying this example to the acquisition of J.C. Penney by Pershing Square and Vornado Realty Trust indicates that the delayed disclosure filing fee on the acquisitions during the ten-day window would be $\$ 37,135,864$ and $\$ 6,002,398$, respectively. ${ }^{201}$ These are far lower than the actual potential profits the hedge funds obtained, suggesting that the fee would not have prevented activism in this instance. But it would have reduced the payoff of intervention and forced these hedge funds to internalize the approximate social cost of trading on asymmetric information during the delayed disclosure window.

Of course, the discussion thus far has only been a hypothetical example of how a nonlinear delayed disclosure fee might operate. A greater challenge is to determine the correct rates, i.e., the empirical distribution of social cost resulting from delayed disclosure at different durations. Initially, a quadratic function might be utilized, under the intuition that distrust in capital markets would become substantially worse for each additional day of delayed disclosure and each additional percent of ownership acquired. But it is also essential to ascertain the more specific characteristics of the distribution of the social cost of delayed blockholder disclosure. This cost may be discontinuous. Certain levels of delayed disclosure may lead to a jump in distrust of capital markets. Accordingly, setting the fee rates with a quadratic function should only be a rough initial approximation.

Finding the empirical social cost of delayed disclosure can be accomplished through a continual process of surveying and experimentation. The SEC might, for example, randomly survey market makers and individual investors upon the filing of a schedule 13D as to how the stealth acquisition of shares during delayed disclosure window

\footnotetext{
${ }^{201}$ The calculation is as follows. Pershing Square acquired $10.2 \%$ of J.C. Penney over a period of 10 days at a total purchase price of $\$ 742,717,279$ (treating options as equal to the purchase price plus strike price and cash-settled total return swaps as equal to purchasing the underlying equity) $*$ fee rate of $5 \%=\$ 37,135,864$. Vornado acquired $3.3 \%$ of J.C. Penney over a period of 10 days at a total purchase price of $\$ 219,868,049$ (treating options as with Pershing Square and forwards at the initial reference price) * $2.73 \%=\$ 6,002,398$.
} 
affected bid/ask spreads and their participation in the market. ${ }^{202}$ The SEC could compare trading patterns of individual investors who had traded with a stealth acquirer to those who had not. A well-designed empirical study could reveal much about the social cost of delayed disclosure. ${ }^{203}$

\section{Compensating Victims of Delayed Disclosure}

As described above, there are two primary sources of social cost imposed by delayed blockholder disclosure—one consequentialist and the other deontological. It is essential to recognize at the outset that any efficient mechanism to internalize the social cost of delayed disclosure can necessarily only address these two sources imperfectly. On the consequentialist level, it may be impossible to ensure that investors who sell shares to hedge funds trading on asymmetric information will be fully compensated while still preserving an efficient level of hedge fund activism. This is because the pursuit of efficiency requires incentivizing the level of hedge fund activism that is optimal for a firm and society as a whole, even if that means transferring wealth from selling shareholders to the acquiring hedge fund.

In other words, a relatively short disclosure delay may be optimal for firms and society as a whole, but it may still impose losses on trading counterparties that exceed any amount that can be internalized while still retaining an efficient level of activism. On the deontological level, it may be that no monetary compensation can adequately remedy the injury to counterparties' autonomy.

Nonetheless, a compensation system should be instituted to ameliorate the injury to victims of trading on asymmetric information. This could be accomplished by establishing a dedicated fund to which the proceeds of the delayed disclosure fee would be directed. Individuals or firms who sold shares during the delayed disclosure period prior to a

\footnotetext{
${ }^{202}$ For a discussion of the use of randomization to set legal and regulatory policy, see generally Michael Abramowicz, Ian Ayres \& Yair Listokin, Randomizing Law, 159 U. PEnN. L. Rev. 929 (2011).

${ }^{203}$ However, as discussed in the Appendix, finding a single optimal mandatory disclosure length for the distribution of the firm-specific costs and benefits of delayed blockholder disclosure is extraordinarily difficult.
} 
blockholder's schedule 13D announcement and during the number of days authorized by the private ordering amendment to the company's bylaws would be eligible to receive compensation for their losses.

The mechanics of the compensation system are straightforward. An investor's "loss" should be defined as the difference between the investor's sale price during the delayed disclosure window and the closing price on the first trading day following the schedule 13D filing. ${ }^{204}$ As administrator of the compensation scheme, the SEC could reduce an investor's loss if there is objective evidence that the sale price or the closing price on the day of disclosure was depressed or inflated by some other, unrelated event such as a poor earnings announcement or sharp decline in the firm's sector or market as a whole. ${ }^{205}$

An investor's "loss" would serve as a benchmark for a proportional allocation of the funds available in the compensation fund on a periodic basis. If the total aggregate losses among investors in a given period (e.g. tax year) are equal to or less than the funds available in the compensation fund, every investor will receive full compensation for his or her losses. In the more likely scenario where the aggregate losses exceed the available funds, each investor will receive a proportion of the available funds equal to his or her proportion of the total losses. For example, if aggregate losses total $\$ 1$ million of which an investor has lost $\$ 100,000$, but the available funds in the compensation fund for that tax year equal $\$ 500,000$, that investor would receive $\$ 50,000$.

This definition of "loss" is similar to the approach utilized in traditional securities litigation. Under Dura Pharmaceuticals, Inc. v. Broudo, ${ }^{206}$ in a securities fraud lawsuit "an inflated purchase price will not itself constitute or proximately cause the relevant economic loss.",207 However, the Court emphasized, "[i]f the purchaser sells later after the

\footnotetext{
${ }^{204}$ The closing price on the day after disclosure is more preferable than a later date, e.g., the ten-day post-disclosure closing price that was used to demonstrate a hedge fund's potential profit in Section II.A. Investors could presumably sell immediately upon the schedule 13D announcement to benefit from the higher share price, whereas the hedge fund could not realistically sell its entire stake on the day of disclosure (thus making a ten-day period a more reasonable comparison).

${ }^{205}$ See discussion infra p. 62.

${ }^{206} 544$ U.S. 336 (2005).

${ }^{207} I d$. at 342.
} 
truth makes its way into the marketplace, an initially inflated purchase price might mean a later loss."208

The Court's statement in Dura reflects the rationale behind this Article's proposal to define an investor's “loss” from delayed blockholder disclosure as the difference between the sale price and the closing price on the date of the schedule 13D filing. An announcement that a hedge fund has acquired over $5 \%$ of the beneficial ownership of a reporting company is the disclosure of material information, i.e., the "truth mak[ing] its way into the marketplace." The closing price as of the day immediately after the 13D announcement most likely reflects the effect of the disclosure on the share price rather than other factors.

Permitting the SEC to adjust the "loss" calculation based on objective evidence that some other factor affected the share price either at the time of sale or on the day of disclosure comports with the following rationale articulated by the Court in Dura:

When the purchaser subsequently resells such shares, even at a lower price, that lower price may reflect, not the earlier misrepresentation, but changed economic circumstances, changed investor expectations, new industry-specific or firm-specific facts, conditions, or other events, which taken separately or together account for some or all of that lower price. $^{209}$

To the extent that an investor's loss was caused by some factor other than delayed blockholder disclosure, it should not be compensable under this compensation regime. $^{210}$

Unlike with securities fraud, however, articulating a clear standard for disproving causation in the delayed disclosure context is challenging. In Lentell v. Merrill Lynch \& Co., Inc., the Second Circuit held that "a plaintiff must allege ... that the subject of the fraudulent statement or

${ }^{208} I d$. at 342.

${ }^{209} I d$. at $342-43$.

${ }^{210}$ Admittedly, this would be difficult to establish in practice, but such an adjustment should be provided for to ensure that the compensation system is not being exploited to simply insure against downturns in share prices. 
omission was the cause of the actual loss suffered." "111 With delayed blockholder disclosure, however, there is no specific "subject of the fraudulent statement or omission" beyond the lack of filing a schedule $13 \mathrm{D}$ prior to the moment of trading and the simultaneous non-disclosure of the blockholder's accumulated stake. Accordingly, while it is quite reasonable for the SEC to use the difference in the closing price on the day of disclosure and the purchase price as a presumption of an investor's loss, it is difficult to identify a set of objective criteria that the SEC could employ to discount this sum in response to other factors.

The most practicable solution is simply to entrust the SEC with the discretion to adjust the claim by major firm-specific, sector, or marketrelated developments, but otherwise to rely on the share price differential as a reasonable approximation of an investor's loss. Unlike with securities fraud litigation, erring on the side of generally awarding investors "too much” would not lead to excessive recovery. Under this proposal, the compensation system would apportion the available funds according to investors' relative loss. As long as any error in computing investors' losses is distributed similarly across investors, this would not lead to any single investor receiving an excessive recovery because the proportional shares for distributing the available funds would remain identical. ${ }^{212}$

Again, the purpose of this compensation system is not to fully recompense victims of trading with asymmetric information. ${ }^{213}$ From a social welfare perspective, the pursuit of Kaldor-Hicks efficiencyproduing gains to society that exceed losses-is normatively superior. The fundamental goal of the filing fee proposal is to induce socially efficient durations of delayed blockholder disclosure. However, within this framework, it is possible to ameliorate the injury of information asymmetries using a redistributive compensation system.

${ }^{211} 396$ F.3d 161, 173 (2d Cir. 2005) (internal quotation marks omitted) (quoting Suez Equity Investors, L.P. v. Toronto-Dominion Bank, 250 F.3d 87, 95 (2d Cir. 2001)).

${ }^{212}$ However, relative disparities between investors may still result under this proposal if certain investors are able to make a greater loss claim because of external factors and the SEC cannot unequivocally distinguish these cases from cases where the loss is truly caused by delayed disclosure.

${ }^{213}$ As noted previously, deontological harm simply may not be compensable. 
A PRIVATE ORDERING SOLUTION TO BLOCKHOLDER DISCLOSURE

$1 / 10 / 13$

\section{CONCLUSION}

This Article's contribution is simple: in the debate over blockholder disclosure, we have been asking the wrong questions. It is not enough merely to point to the fact that hedge fund activism might benefit target firms. Nor is Congress's intent from the 1960s dispositive regarding the role hedge funds should play in corporate governance today. The important question is what legal rule would maximize the net benefit to society as a whole. Society is better off when outside blockholders reduce managerial slack and agency costs-but only when doing so does not come at the expense of long-term value creation. Society is worse off when trading on asymmetric information engenders distrust in capital markets and violates the autonomy of parties who are less informed. Any policy solution must take into account these costs and benefits.

Private ordering is the best solution to finding an optimal balance. No party has a better incentive to reduce managerial slack and enhance long-term value than a firm's shareholders. Allowing firms to opt-out of immediate disclosure through a shareholders' amendment to the bylaws puts the power in shareholders' hands to allow the level of delayed disclosure optimal for each firm. But we also cannot ignore the social cost of trading on asymmetric information. The SEC should impose a delayed disclosure fee that would reflect the harm suffered by society when hedge funds profit from the non-disclosure of material, nonpublic information regarding share accumulation and control intent. A compensation fund would soften the blow of trading while a better informed trading counterparty exploited a legally sanctioned delayed disclosure window.

The approach suggested by this Article has implications for other areas of securities law as well. Too often policymakers have imposed a suboptimal mandatory rule instead of balancing costs and benefits and considering empowerment approaches such as opt-out, taxing, and compensation. Insider trading is a prime example. With so many resources spent on enforcing an absolute ban, ${ }^{214}$ we should at least

${ }^{214}$ See SECURITIES AND EXCHANGE COMmission, In BRIEF: FY 2013 CONGRESSIONAL JuSTIFICATION 13, available at http://www.sec.gov/about/secfy13congbudgjust.pdf (FY 2012 estimated expenses for the Division of Enforcement total \$467,317,000 and request for FY 2013 is $\$ 512,854,000)$. 
consider the alternatives. A private ordering approach coupled with a tax on insiders' profits and compensation for victims could enhance price accuracy while ameliorating the injury to trading counterparties. Regulators might even reconsider mandatory rules entirely, as transactional bargaining could facilitate even greater efficiency. ${ }^{215}$

For blockholder disclosure, a private ordering solution is the place to start. As financial innovation makes acquiring equity ownership faster than ever, ten days of deceptive trading may induce substantial instability and among target firms and a detrimental focus on short-term results. Numerous accounting scandals over the years have shown the cost of ascribing too much weight to quarterly earning reports. For society as a whole, the day may come when ten days of legally sanctioned exploitation of information asymmetries would impose too great of a price on participation in the capital markets for many retail investors.

On the other hand, eliminating the disclosure window entirely may very well drive away those investors who Jonathan Macey correctly called "the last bidders who still may be able to make money in the market for corporate control."216 In the face of empirical evidence that hedge fund activism may benefit target firms, we should ask ourselves whether removing this financial incentive is the right approach. The truth may not always be in the middle, ${ }^{217}$ but when it comes to blockholder disclosure, the optimal solution requires a careful balance.

\footnotetext{
${ }^{215}$ See generally Brams \& Mitts, supra note 137, at [•] (advocating bargaining mechanisms for blockholder disclosure and more generally).

${ }^{216}$ Jonathan Macey, Uncle Sam and the Hostile Takeover, WALL ST. J. (Mar. 21, 2011), http://online.wsj.com/article/SB10001424052748704608504576208900109315200.html.

${ }^{217}$ See RoBert J. Gula, NonSENSE: A HANDBOOK OF LOGICAL FALlacies 102 (2002) (discussing the false mean fallacy).
} 
A PRIVATE ORDERING SOLUTION TO BLOCKHOLDER DISCLOSURE

\section{APPENDiX: A Simple Model ANd Challenges of STATISTICAL INFERENCE}

A central thesis of this Article is that both the costs and benefits of delayed blockholder disclosure must be considered when setting regulatory policy. There is no a priori justification for concluding that ten days promotes an optimal level of hedge fund activism for target firms and society at large. Conceptually, the optimal disclosure window $x$ is the length of time that incentivizes the level of hedge fund activism with the aggregate marginal benefit from monitoring management equal to its aggregate marginal cost, which consists of the sum of the firm-specific costs of short-termism plus the economic and non-economic social costs of delayed disclosure. It is helpful to consider this equation algebraically:

$b_{\mathrm{i}}(x)=$ the total benefit to firm $i$ from blockholder disclosure duration $x$ $c_{\mathrm{i}}(x)=$ the total cost to firm $i$ from blockholder disclosure duration $x$ $n=$ the number of firms subject to the Exchange Act reporting requirements

$$
\begin{aligned}
& B(x)=b_{1}(x)+b_{2}(x)+\ldots+b_{\mathrm{n}}(x) \\
& C(x)=c_{1}(x)+c_{2}(x)+\ldots+c_{\mathrm{n}}(x) \\
& S(x)=\text { the total cost to society from blockholder disclosure } \\
& \text { duration } x \text {. }
\end{aligned}
$$

The optimal aggregate duration $x$ would then be given by:

$$
B^{\prime}(x)=C^{\prime}(x)+S^{\prime}(x)
$$

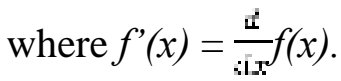

The problem, of course, is that $b_{\mathrm{i}}(x), c_{\mathrm{i}}(x)$, and $S(x)$ are unknown. There is no predefined mathematical function giving the exact costs and 
benefits of delayed blockholder disclosure. Moreover, while it might be possible to use surveys and experimental techniques to discover the firmspecific benefits, costs, and social cost of delayed blockholder disclosure at different durations, problems of estimation remain. Consider the following general form of a parametric model to estimate the coefficients for the correlation between different durations of delayed disclosure and the corresponding costs and benefits:

$$
\begin{aligned}
& B=m_{B}\left(\beta_{B}, X, \epsilon_{B}\right) \\
& C=m_{C}\left(\beta_{C}, X, \epsilon_{C}\right) \\
& S=m_{S}\left(\beta_{S}, X, \epsilon_{S}\right) \\
& \text { where } B=\text { observed aggregate firm-specific benefits, } \\
& C=\text { observed aggregate firm-specific costs, } \\
& S=\text { observed social costs, } \\
& m=\text { a parametric model of the data, } \\
& \beta=\text { parameters to be estimated by } m \text {, } \\
& X=\text { different delayed durations, } \\
& \epsilon=\text { random error terms }
\end{aligned}
$$

In theory, once the parameters $\beta_{B}, \beta_{C}$, and $\beta_{S}$ are estimated, the functions $B(x), C(x)$, or $S(x)$ could be approximated and the optimal value of $x$ estimated by equation (1). However, it may be difficult to find an appropriate functional form for the models $m_{B}, m_{C}$, and $m_{S}$ to fit the distribution of $B, C$, and $S$. For example, as discussed above, the social cost of delayed disclosure may "jump up” at various levels. Individual firm costs and benefits, e.g., $b_{\mathrm{i}}(x)$ and $c_{\mathrm{i}}(x)$, may be wildly unpredictable, e.g., if certain firms would experience an extraordinarily high cost for short disclosure while others might derive great benefit from hedge fund activism. In this case, the random errors $\epsilon_{B}, \epsilon_{C}$, and $\epsilon_{S}$ would not necessarily be normally distributed. Hypothesis testing based on traditional assumptions of normality of the errors would be inconsistent. More fundamentally, estimating confidence intervals is extremely challenging without an accurate population model.

Put differently, the optimal disclosure length for individual firms may be so unpredictable that it may be impracticable to identify an ideal 
universal mandatory duration. This suggests that the right approach to reforming the blockholder disclosure window is to adopt a legal rule that encourages each firm $i$ to find the optimal disclosure length $x_{i}$ for itself, taking into account the social cost of such a duration. Indeed, even if a mandatory duration could be estimated statistically, it is still likely to be inferior to a private ordering solution that induces an optimal duration for each firm. A single duration would necessarily be over- and underinclusive compared to a firm-specific approach. In algebraic terms, the optimal firm-specific duration $x_{i}$ for firm $i$ is given by:

$$
b_{i}^{\prime}\left(x_{i}\right)=c^{\prime}{ }_{i}\left(x_{i}\right)+S^{3}{ }_{i}\left(x_{i}\right)
$$

where $S_{i}^{\wedge}\left(x_{i}\right)=$ the proportional total social cost of delayed disclosure attributable to firm $i$ from delayed blockholder disclosure with duration $x_{i}$.

Equation (3) brings us one step closer to a concrete policy proposal to reforming the section 13(d) blockholder disclosure window. The ideal rule should encourage the discovery of $x_{i}$ by equalizing each firm's marginal benefit and marginal cost functions from delayed blockholder disclosure plus the marginal proportional social cost of such a delay $x_{i}$ attributable to firm $i$. Moreover, it is essential to consider the population distribution of $B, \mathrm{C}$, and $S$. In particular, if $S$ is nonlinear, internalizing the social cost of delayed blockholder disclosure would require a more sophisticated approach than simply imposing a flat fee on delayed disclosure. This is discussed further in Section IV.C. 